Review

\title{
Signaling Pathways That Control Apoptosis in Prostate Cancer
}

\author{
Amaal Ali ${ }^{1}$ and George Kulik ${ }^{2,3, *}$ \\ 1 Life Sciences Program, Alfaisal University, Riyadh 11533, Saudi Arabia; aaali@alfaisal.edu \\ 2 Department of Life Sciences, Alfaisal University, Riyadh 11533, Saudi Arabia \\ 3 Department of Cancer Biology, Wake Forest University Health Sciences, Medical Center Blvd, \\ Winston-Salem, NC 27157, USA \\ * Correspondence: gkulik@alfaisal.edu
}

check for

updates

Citation: Ali, A.; Kulik, G. Signaling Pathways That Control Apoptosis in Prostate Cancer. Cancers 2021, 13, 937. https://doi.org/10.3390/

cancers13050937

Academic Editor: Tadeusz Malewski

Received: 26 January 2021

Accepted: 18 February 2021

Published: 24 February 2021

Publisher's Note: MDPI stays neutral with regard to jurisdictional claims in published maps and institutional affiliations.

Copyright: (c) 2021 by the authors. Licensee MDPI, Basel, Switzerland. This article is an open access article distributed under the terms and conditions of the Creative Commons Attribution (CC BY) license (https:// creativecommons.org/licenses/by/ $4.0 /)$.
Simple Summary: Therapies that inhibit androgen receptor signaling induce cell death by apoptosis in prostate epithelium and involution of non-malignant prostate gland, but are not effective against advanced prostate cancer. Recent evidence suggests that activation of androgen receptors in prostate stroma cells induces secretion of paracrine factors that control apoptosis in prostate epithelium. The nature of these paracrine factors, and of the signaling pathways they activate in prostate epithelial cells as well as the apoptosis regulating molecules targeted by these pathways remains unknown. This review summarizes the information on the proteins that regulate apoptosis in prostate cells, on signaling pathways that regulate these proteins, and provides an overview of clinical trials that target signaling pathways in prostate cancer. Understanding the intercellular communications and apoptosis regulation in normal prostate glands and in prostate tumors is essential for the design of curative personalized therapies for advanced prostate cancer.

Abstract: Prostate cancer is the second most common malignancy and the fifth leading cancercaused death in men worldwide. Therapies that target the androgen receptor axis induce apoptosis in normal prostates and provide temporary relief for advanced disease, yet prostate cancer that acquired androgen independence (so called castration-resistant prostate cancer, CRPC) invariably progresses to lethal disease. There is accumulating evidence that androgen receptor signaling do not regulate apoptosis and proliferation in prostate epithelial cells in a cell-autonomous fashion. Instead, androgen receptor activation in stroma compartments induces expression of unknown paracrine factors that maintain homeostasis of the prostate epithelium. This paradigm calls for new studies to identify paracrine factors and signaling pathways that control the survival of normal epithelial cells and to determine which apoptosis regulatory molecules are targeted by these pathways. This review summarizes the recent progress in understanding the mechanism of apoptosis induced by androgen ablation in prostate epithelial cells with emphasis on the roles of BCL-2 family proteins and "druggable" signaling pathways that control these proteins. A summary of the clinical trials of inhibitors of anti-apoptotic signaling pathways is also provided. Evidently, better knowledge of the apoptosis regulation in prostate epithelial cells is needed to understand mechanisms of androgenindependence and implement life-extending therapies for CRPC.

Keywords: prostate cancer; androgen independence; CRPC; apoptosis; signaling; clinical trials

\section{Introduction}

Prostate cancer (PCa) is the second most diagnosed malignancy in men and the fifth leading cause of death from cancer worldwide. A total of 1,276,106 PCa cases and 358,989 deaths were reported across the world in 2018 , making up $7.1 \%$ of all cancers diagnosed and $3.8 \%$ of all cancer-caused deaths in males [1]. On a global scale, the number of diagnosed cases of PCa is rising, although, PCa incidence varies between countries by more than 25 -fold, [1,2]. The main socio-demographic factors that contribute 
to growing PCa incidence include increased animal fat consumption and growing elderly population [3].

Transformation of normal prostate tissue to PCa is a multistep process that involves the transition of the normal prostate to high grade prostatic intraepithelial neoplasia and then to localized and to advanced prostatic adenocarcinoma. For locally confined $\mathrm{PCa}$, the choice of treatment is either surgical resection or radiation therapy or both [4,5]. However, while those therapies cure organ confined $\mathrm{PCa}$, if the disease reoccurs it often metastasizes; thereby, complicating its treatment [6]. The first line therapy for locally advanced, recurrent or metastatic PCa is androgen deprivation therapy (ADT) [4,7-14]. ADT can be achieved by either surgical castration or pharmacological castration using anti-androgens such as bicalutamide or next generation therapies such as enzalutamide (MDV3100) $[6,8,15,16]$. Although advanced and metastatic PCa initially respond to ADT, PCa cells eventually become castration resistant causing nearly all PCa patients to relapse $[4,9]$.

In most cases, castration resistant PCa (CRPC) cells continue to express an androgen receptor (AR), that could be aberrantly reactivated even in conditions of androgen deprivation [9]. When the next generation of AR-targeting therapies that prevent reactivation of AR entered clinical practice, a new evidence of increased proportion of CRPC that lost AR expression altogether has emerged from the analysis of resistant tumors $[15,17,18]$.

Currently, the main approved chemotherapy for CRPC is docetaxel. Other approved treatments for CRPC include the immunotherapy agent sipuleucel-T and the taxane cabazitaxel. However, even with those drugs and many others in clinical trials, CRPC remains incurable [19]. Further complicating PCa treatment is the high degree of heterogeneity among PCa. Therefore, there is an urgent need for a novel and personalized approaches supplementing or even replacing ADT for treatment of PCa [20,21].

To find effective therapies it is essential to understand the mechanisms of androgen independence in CRPC, which is impossible without the knowledge of how androgen receptor signaling regulates the homeostasis of a normal prostate. Several forms of cell death and cell senescence may contribute to the prostate gland homeostasis, yet we choose to focus on apoptosis, since it is well documented in rodent models and is demonstrated by the analysis of human prostates that androgen deprivation induces apoptosis in the epithelial cells of the prostate gland and results in the involution of the gland [22,23].

The evidence from tissue recombination experiments and from the single cell gene expression analysis in the prostate gland suggest that AR signaling in the stroma triggers production of paracrine factors that control apoptosis in epithelial cells. The identity of these paracrine factors and of the mechanisms these factors engage are yet to be understood.

In this review we discuss recent information on apoptosis regulation in prostate epithelial cells, the role of BCL-2 family proteins in this process and the signaling pathways that target these proteins. We choose to focus on "druggable" signaling pathways for which clinically approved inhibitors have been developed and to provide an overview of clinical trials that test inhibitors of the anti-apoptotic signaling pathways in CRPC.

\section{Apoptosis in Prostate Epithelial Cells Is Controlled by AR Signaling in Stroma}

\subsection{Stroma and Luminal Compartments of the Prostate Gland}

The human prostate gland consists of two cellular compartments: an epithelial compartment that contains luminal and basal epithelial cells, and a stromal compartment which surrounds the epithelial layer. Luminal epithelial cells are polarized, columnar cells that form a layer that lines the lumen of the prostate. The luminal epithelium expresses high levels of the AR and cytokeratins 8 and 18, CD57, NKX3.1, as well as secretory proteins such as the prostate specific antigen (PSA). The basal epithelial cells are non-secretory cells that line the basement membrane and separate the lumen from the stroma. The basal epithelium expresses the cellular markers cytokeratin 5 and 14, p63, CD44, and GSTP1. Unlike luminal cells, basal cells express low AR levels. Rare neuroendocrine cells are also found within the basal compartment. Neuroendocrine cells are AR-negative cells that secrete neuropeptides, and the growth factors for luminal cells. Neuroendocrine cells also 
frequently display dendritic-like processes that can contact luminal cells. The stromal compartment surrounds the epithelial compartment and contains a large number of fibroblasts that secrete components of the extracellular matrix that maintains organ integrity and mediates signaling by growth factors; and also contains a layer of smooth muscle cells lining the epithelium that can contract and aid in the forceful discharge of the prostatic fluid. The stroma contains other components including blood vessels, lymphatics, nerves, and immune cells [4,24] (Figure 1).

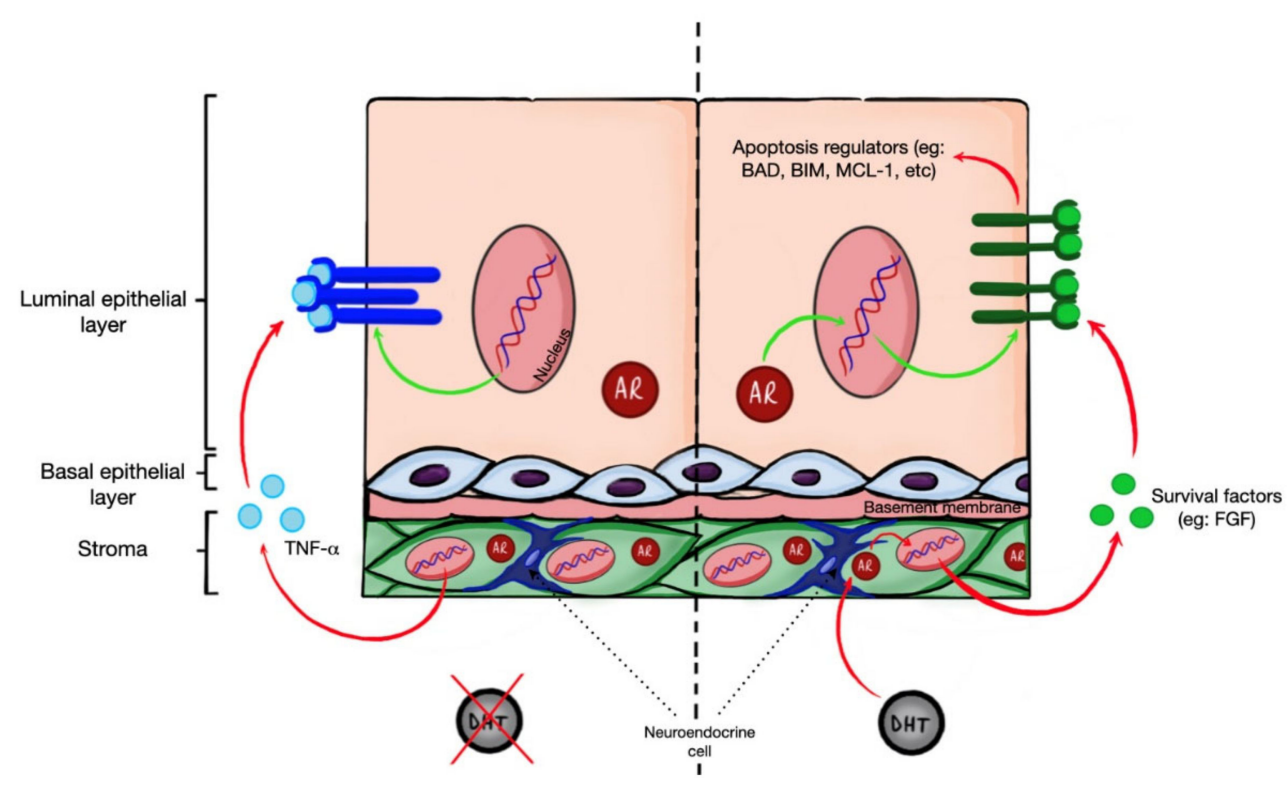

Figure 1. Androgen receptor (AR)-induced paracrine factors regulate apoptosis in prostate epithelial cells. Paracrine factors secreted by fibroblasts, neuroendocrine and other stroma cells regulate prostate tissue homeostasis. In stromal fibroblasts AR induces expression of survival factors that act on luminal epithelial cells. In prostate epithelial cells AR signaling increases expression of receptors of survival factors. Inhibition of AR signaling leads to increased production of TNF- $\alpha$ by stroma.

\subsection{Androgen Ablation Triggers Apoptosis}

The normal growth, differentiation and functioning of the prostate gland as well as the growth and progression of PCa depends on signaling by the AR activated by the steroid hormones androgens [7,25-27]. Two androgens, testosterone and its more potent metabolite, dihydrotestosterone (DHT), can regulate the AR's transcriptional activity [25]. In the prostate, testosterone, the primary circulating androgen in men, is converted to the more potent and major AR-bound androgen DHT, by the enzyme $5 \alpha[9]$-reductase $[25,26]$. In the absence of androgens AR is sequestered in the cytoplasm by heat shock proteins (HSPs) and present in an inactive yet poised-for-activation state [7,25]. Upon binding of androgens, AR undergoes conformational change [28], dissociates from HSPs and is activated [7,25-27]. Active AR dimerize and translocate to the nucleus where they bind through DNA-binding domain to androgen-responsive element (ARE) in the promoter and enhancer regions of AR's target genes [27]. Coactivators, complexes that modify chromatin, and RNA polymerase II are then recruited, and transcription of the target genes is induced or repressed [7].

Pioneering work of Huggins and Hodges on involution of the prostate gland after bilateral orchiectomy in dogs [29] was followed by studies by J.F. Kerr in rats that demonstrated dramatic involution of the ventral prostate gland (VP) after castration, with marked decline of organ weight on day 3 post castration that continued until days 15-21 [22]. Detailed analysis by electron microscopy (EM) showed the presence of autophagic vacuoles, condensation and fragmentation of cytoplasm and nuclei as well as the presence of fragmented cells engulfed by macrophages and neighboring epithelial cells indicative of 
cell death by apoptosis [22,30]. Time course analysis demonstrated an increased percentage of apoptosis on day 2 with maximal increase in percent of apoptotic cells at day 3 post castration that declined from day 4 and until days 13 and 20 [22,31]. The majority of apoptotic cells were found in the epithelial layer although occasionally clusters of apoptotic bodies were found in the acinar lumina [22]. These EM and cytohistologic data were interpreted as an evidence of cell death by apoptosis as a main cause of VP involution in castrated rats.

The analysis of mechanisms of VP involution in castrated rats was expanded by John Isaacs' group that demonstrated DNA fragmentation in epithelial cells, a classic apoptosis hallmark. Based on a detailed analysis of the apoptotic index by TUNEL (terminal deoxynucleotidyl transferase dUTP nick end labeling), a method that detects cells with fragmented DNA and analysis of mitotic index by in-vivo ${ }^{3} \mathrm{H}$-tymidine labeling they concluded that involution of VP can be explained by the combination of decreased proliferation and increased apoptosis $[23,32]$. The leading role of apoptosis in prostate involution is further supported by experiments with prostate-restricted expression of BCL2. Transgenic mice that expressed BCL2 under probasin promoters showed a significantly lower percent of apoptotic cells after androgen ablation when compared to wild-type mice [33].

\subsection{Role of Stromal AR in Epithelial Apoptosis Regulation}

Studies in animal models by several research groups reported that apoptosis was found mostly in columnar epithelial cells that were eliminated after androgen deprivation, yet regenerated when androgen levels were restored [23]. The question remained, however, whether AR functions in "cell autonomous fashion" by directly regulating expression of genes that control apoptosis in luminal epithelial cells, or apoptosis is regulated by paracrine factors secreted in response to androgens.

To examine the cell autonomous role of AR in apoptosis, tissue recombination experiments were conducted to combine epithelium from Tfm mice (that lack AR expression due to spontaneous mutation on the $\mathrm{X}$ chromosome) with stroma from wild-type mice. In the recombined prostate tissue that expresses AR only in stromal cells, castration induced apoptosis in epithelial cells lacking AR with an apoptotic index nearly the same as that of wild-type mice. Administration of testosterone and dihydrotestosterone equally reversed apoptosis in AR-negative and AR-positive epithelial cells. These data suggests that apoptosis in luminal epithelial cells is not directly regulated by epithelial AR, but instead is regulated by paracrine factors (for example FGF10) induced by androgens through AR expressed in stromal cells [34,35]. At the same time, experiments in transgenic mice with $\mathrm{AR}$ knockout driven by $\mathrm{Pb}$ promoter showed increased apoptosis in CK8-positive luminal epithelial cells, increased proliferation in CK5-positive basal epithelial cells, and stromal atrophy [36-38]. The earlier report showed increased Ki-67 staining and increased apoptosis in prostate secretory epithelial cells in transgenic mice with overexpression of AR driven by $\mathrm{Pb}$ promoter [39]. These discordant reports on the role of $\mathrm{AR}$ in regulation of apoptosis and proliferation from the groups that used tissue recombination and $\mathrm{Pb}$-driven transgenes illustrate challenges of analysis of the inter-cellular and intra-cellular communications that regulate homeostasis in prostate tissue.

Experiments with selective AR knockout in smooth muscle cells [40,41]; in stromal fibroblasts [42] and in both smooth muscle and stroma fibroblasts [43] (reviewed in [44]) point at a paracrine mechanism. Thus, activation of AR in prostate stroma cells induces expression of signaling molecules (FGFs, IGF-I, and others) that in turn control survival of luminal epithelial cells and morphogenesis of the prostate gland.

Perhaps the most conclusive evidence comes from the publication that used tamoxifenactivated CRE to induce AR knockout in basal and luminal prostate epithelial cells of 8-week-old mice and followed apoptosis, proliferation and gene expression at a single cell level. AR knockout in luminal cells did not change apoptosis, involution and regeneration of luminal cells during the castration/regeneration cycle [45].

Another recent report on the single cell RNAseq profiling of anterior prostate in mice provided a comprehensive analysis of cell populations that constitute epithelial and 
stromal compartments and their dynamics during the castration-regeneration cycle [35]. Luminal secretory cells that constituted the majority in the epithelial compartment were identified as the main cell type that contributes to regeneration by increased proliferation after circulating androgen levels are restored. The profiling of stroma cells demonstrated substantial changes in the expression of growth factor genes (Nrg2, Igf1, Fgf10, Rspo3) and increased expression of corresponding receptors FGFR2 and LGR4 in luminal epithelial cells in response to androgen. The importance of the FGF/ERK pathway for the ADT-resistance has been recently demonstrated in several PCa cell lines [17].

In addition to the induction of apoptosis in epithelial cells, apoptosis in endothelial cells of the prostate stroma has been reported [46]. Decreased blood flow [47] and hypoxia [48] have been also connected with apoptosis of prostate epithelial cells, however, later studies did not detect hypoxia after castration [28].

Altogether results from experiments with tissue recombination, prostate-restricted transgenes, and single cell RNAseq analysis suggest that despite high AR expression in prostate epithelia, the growth and survival of prostate epithelial cells is not directly regulated by epithelial AR. Instead, AR-dependent expression of growth and survival factors by cells in stromal compartment regulates proliferation and survival of luminal epithelial cells in paracrine fashion (Figure 1).

New evidence on indirect paracrine regulation of the prostate epithelial cells through AR signaling in the stroma challenges the current practice of indiscriminate androgen ablation therapy and harbingers a need for therapies selectively targeting AR's in the tumor stroma [38]. More experiments utilizing inducible transgenes in combination with the single cell genomic and proteomic studies are needed to identify paracrine factors that control apoptosis in prostate cancer cells after androgen ablation. Equally important is to understand which apoptosis regulatory molecules are controlled by these paracrine signals.

\subsection{Roles of Mitochondrial and Death Receptor-Induced Apoptosis in Prostate Involution}

Apoptosis in prostate epithelial cells can be induced by mitochondrial (intrinsic), or death receptor (extrinsic), pathways. The extrinsic apoptotic pathway is initiated by activation of death receptors belonging to the tumor necrosis factor (TNF) family: TNFRSF1A, FAS (CD95, or APO-1), TNFSF10/TRAIL receptors TNFRSF10A/DR4, TNFRSF10B/DR5, TNFRSF25/DR3 and TNFRSF21/DR6 [49]. When bound by their ligands, death receptors cluster to form the death-inducing signaling complex (DISC) that activates the initiator caspases 8 and 10. Active caspases 8 and 10 then activate the effector caspases 3,6 and 7 that cleave substrates resulting in apoptosis. The extrinsic apoptotic pathway can be inhibited by the protein CFLAR/FLIP [50].

FAS and FASLG/FASL are expressed in mouse and human prostate tissues as well as PCa cell lines [51-54]. The paper by Suzuki et al. reported that prostates in $l p r$ mice (lacking functional FAS) do not undergo involution in response to castration [55]. Another study showed 3-5-fold upregulation of FASL mRNA and protein observed 3 days postcastration, however it did not find significant differences between wild type and $l p r$ mice in castration-induced VP regression or in the counts of apoptotic cells assessed by TUNEL and by morphology of apoptotic bodies [56]. A subsequent study that compared castration-induced prostate involution in wild type, $\mathrm{Tnf}^{-1}, \mathrm{Tnfr}^{-{ }^{--}}$, $\mathrm{Trail}^{-/}$or $\mathrm{lpr}$ mice demonstrated that diminished prostate involution was evident only in Tnf ${ }^{/}$and $\operatorname{Tnfr}^{-1}$ mice with impaired TNFR1 signaling, but not in $l p r$ mice. Delay in prostate involution was also observed in mice injected with TNF-R2-Fc, a soluble TNF-R2 that can prevent activation of membrane bound TNFR1 by TNF- $\alpha$. Conversely, increased production of TNF- $\alpha$ by the stroma of castrated mice was reported, whereas, injecting castrated Tnf ${ }^{-/-}$ mice with TNF- $\alpha$ restored prostate involution to the levels seen in WT mice. Data from this publication support the hypothesis that androgen ablation induces TNF- $\alpha$ production by prostate stroma that act on TNFR1 in luminal epithelial cells to induce apoptosis and prostate involution. However, despite slower prostate involution, no differences in apoptotic indices between WT and $\mathrm{Tnf}^{-/-}$or Tnfr1 ${ }^{-/-}$mice was found. Furthermore, 
TNF- $\alpha$ did not induce involution in non-castrated mice, suggesting that castration not only increases TNF- $\alpha$ levels but also makes luminal cells sensitive to TNF- $\alpha$ induced apoptosis. A possible candidate for AR-regulated gene that increases sensitivity to death receptor induced apoptosis could be FLIP, as it acts as the DISC inhibitor downstream of death receptors. Regulation of FLIP by AR pathway was demonstrated in experiments on castrated rats and in prostate cells lines where FLIP levels defined sensitivity to apoptosis induced by TRAIL [57-60].

Evidently more follow-up studies with an inducible knockout of specific death receptors and downstream components of death receptor signaling cascades are needed to clarify the role of death receptors in prostate involution after androgen ablation.

The extrinsic and intrinsic apoptosis pathways are linked by the BH3-only protein BID, yet the role of BID in castration-induced apoptosis was not directly assessed. Instead, an analysis of a mitochondrial pathway in a post-castration prostate gland focused on BAX and BCL2 proteins. Increased levels of BAX and BCL2 were reported in prostate glands of mice after castration [61]. An analysis of apoptosis by counting the percent of TUNEL positive cells in the ventral prostate gland of mice with BAX knockout (Bax ${ }^{-/-}$) showed significantly less apoptosis on day 5 post-castration as compared to wild-type mice, instead, a higher percent of TUNEL positive cells was detected in Bax ${ }^{-/-}$mice on day 1 and day 14 (although the difference did not reach statistical significance). It is worth noting that in other models knockout studies demonstrated redundancy of BAX and BAK [62]. Thus, double knockouts could be necessary to demonstrate the roles of BAX and BAK in castration-induced apoptosis. Similar to the results in $\mathrm{Bax}^{-/-}$mice, a significant decrease in the apoptosis index was observed on day 5 in transgenic mice with BCL2 overexpression targeted to prostate gland by probasin promoters [33]; however, no data on the prostate involution in these mice were reported. Another group generated mice expressing $B c l 2$ transgene under C3(1) promoter, yet no data on castration-induced apoptosis or prostate involution was reported either [63].

Apparently, inactivation of AR in the prostate stroma leads to the increased production of death receptor ligands and the decreased production of survival factors that induce apoptosis in epithelial cells (Figure 1). Altogether, results from transgenic mice suggest that apoptosis regulatory proteins involved in death receptor and mitochondrial pathways collectively regulate apoptosis induced by androgen ablation in prostate gland [64-67].

\section{BCL-2 Family Proteins in Prostate Cancer}

Analysis of gene expression repositories and published data identified BCL2, BCL2L1/ BCLX, MCL1, BAX, BAK, BAD, BCL2L11/BIM, BBC3/PUMA, PMAIP1/NOXA, BIK and $\mathrm{BID}$ as members of the BCL-2 family proteins expressed in a normal prostate and in PCa. Several reviews discuss the contributions of specific anti-apoptotic BCL-2 family proteins to prostate cancer therapy resistance and the targeting of the BCL-2 family by siRNA, antisense DNA or BH3-mimetics [68-70]; however, a comprehensive systems analysis of BCL2 proteins in prostate cancer, and their changes in response to anti-cancer therapies and to anti-apoptotic signals has yet to be performed. Information on the BCL-2 family proteins in prostate cancer is summarized below.

\subsection{Anti-Apoptotic Proteins}

BCL2 - the expression levels of BCL2 are regulated by transcription factors including p53 [71], WT1 [72], and NF- $\kappa$ B [73] and by promoter methylation [74]. Additionally, phosphorylation of BCL2 induced by pro-apoptotic and by anti-apoptotic agents (taxol, IL3 , erythropoietin and bryostatin-1) have been reported. Recent publication demonstrated that BCL2 phosphorylation increased interaction of BCL2 with BAX and BAK; yet decreased interaction between BCL2 and BH3-only pro-apoptotic proteins BIM, PUMA and BAD, and suggested that the ultimate effect of BCL2 phosphorylation on apoptosis is determined by the relative abundance of these pro-apoptotic proteins [75]. 
In the mid to late 90s several groups assessed the roles of BCL2 protein in apoptosis induced in prostate epithelial cells by androgen ablation [76,77]. Increased BCL2 expression after castration was reported in secretory epithelial cells and in basal cells [61,78]. Decreased BCL2 mRNA levels and increased BCL2 promoter methylation was reported in prostate cancer compared to adjacent normal tissue [74]. On the other hand, analysis of changes in expression of androgen regulated genes in human benign prostate tissues xenografts revealed upregulation of BCL2 in response to androgen withdrawal. No changes in the expression of other genes involved in apoptosis regulation has been detected [79]. Earlier immunohistochemical studies reported increased levels of BCL2 protein in prostates of castrated patients [80] and in advanced prostate cancer [78,81]. A negative correlation between AR signaling and BCL2 expression was reported in LAPC4, LAPC9 and LNCaP cells [82] and in prostate tumors [83]. Apparently, increased expression of BCL2 represents a compensatory response by prostate epithelial cells to resist apoptosis induced by androgen ablation and acquire androgen-independence. Thus, ectopic BCL2 expression decreased apoptosis in prostate cancer cells and facilitated the transitioning of PCa cells to androgenindependence in vitro and in vivo $[33,56,84]$. Still, endogenous BCL2 is likely playing a secondary role compared to BCLX and MCL1 that expressed at higher levels in prostate epithelial cells [85].

BCLX-BCLX mRNA expression can be controlled by the transcription factors STAT [86], Rel/NF- $\kappa$ B and ETS [87]; whereas, splicing of the BCLX gene provides another level of BCLX regulation [88]. Post-translational modifications of BCLX by phosphorylation [89] caspase cleavage [90] and deamidation [91] have been reported.

Expression of BCLX was assessed in normal prostate cells, prostate tumors and prostate cancer cell lines [92-95]. Increased BCLX mRNA and protein levels were detected in higher grade tumors, in lymph node metastases and in distant metastases $[92,93,96]$. A positive correlation between BCLX expression and androgen independence was also reported [93]. At the same time, in benign prostate hyperplasia a decreased level of BCLX was found and treatment with $5 \alpha$-reductase inhibitor finasteride did not change BCLX expression [97].

Experiments in prostate cancer cells demonstrated binding of AR to BCLX promoter and AR-dependent regulation of BCLX expression [96]. However recent report on indirect activation of BCLX promoter via AR-> integrin $\alpha 6->N F k B$ mechanism provided more nuanced interpretation of androgen-dependency of BCLX expression in prostate cancer cells [98].

MCL1 mRNA expression analysis suggests that it is the dominant anti-apoptotic protein of the BCL-2 family in prostate cancer cells. Compared to other anti-apoptotic proteins, MCL1 has a longer N-terminus and exists in two forms: a full-length protein localized at the outer mitochondrial membrane that is involved in apoptosis regulation, and a truncated protein that is localized in the mitochondrial matrix and is involved in the mitochondrial dynamics and metabolism. MCL1 is distinguished from other anti-apoptotic members of BCL-2 family by a relatively short half-life, which provides an opportunity for the dynamic regulation of MCL1 protein levels by signaling pathways that control proteostasis.

The activity and levels of MCL1 can be modulated transcriptionally, post-transcriptionally and post-translationally. Transcription of MCL1 can be changed in response to growth factors, cytokines, endoplasmic reticulum (ER) stress, hypoxia and microtubule disruption. Transcription of MCL1 can be regulated by a wide range of transcription factors such as HIF-1, SRF, CREB, c-MYC, ATF5 [99,100]. At the post-transcriptional level, MCL1 can be regulated via pre-mRNA splicing and regulation of the turnover of its short-lived mRNA (half-life of around $2-3 \mathrm{~h}$ ) by the RNA-binding proteins and the multiple regulatory RNAs. Ubiquitination of MCL1 results in its proteasomal degradation, whereas deubiquitination halts MCL1 degradation [100-102]. MCL1 can be phosphorylated on numerous sites and depending on a specific site(s) it can increase or decrease anti-apoptotic capacity. Phosphorylation can modulate inter- 
actions between MCL1 and pro-apoptotic proteins, or it can regulate MCL1 protein stability through interactions with ubiquitin ligases and deubiquitinases [100].

Increased MCL1 expression was reported in PCa, in bone metastases [92,103], and in stem/tumor-initiating cells isolated from prostate tumors [104]. Upregulated MCL1 expression was found in androgen deprived PCa cells both in vitro and in vivo. AR signaling indirectly suppresses mRNA and protein levels of MCL1, but AR does not bind the MCL1 gene and the regulatory mechanism is not understood [104]. Increased MCL1 protein levels in LNCaP cells were connected with autocrine IL6 signaling; yet, no mechanistic data were provided [105]. Activation of ADRB2/PKA signaling protected prostate cancer cells from apoptosis by increasing MCL1 expression via a transcriptionindependent mechanism [106]. Active FLT/VEGFR1, FGFR1 and PDGFR family tyrosine kinases increased the transcription of MCL1 mRNA [103,107] in PCa cell lines. Conversely, inhibitors of tyrosine kinases increased the degradation of MCL1 $[108,109]$. The agents that induce ER stress or inhibit protein synthesis decreased MCL1 expression and sensitized prostate cancer cells to apoptosis $[95,110]$.

Compared to other anti-apoptotic proteins, MCL1 stands out as a convergence node of several signaling pathways that dynamically regulate MCL1 expression levels.

\subsection{Pro-Apoptotic Effector Proteins}

BAX and BAK-can oligomerize and form pores in the outer mitochondrial membrane. BAK is constitutively localized at the mitochondria and undergoes conformational changes during apoptosis that permit homo-oligomerization [65]. BAX is present in a cytosol of healthy cells, and translocates to the mitochondria during apoptosis. Transcription of BAX and BAK can be regulated epigenetically by methylation which suppresses their expression [111].

An analysis of BAX in castrated mouse prostates showed an increased expression in secretory epithelial cells; however, experiments in mice with global knockout of BAX did not show significant differences in the apoptosis index compared to wild type mice [33]. An analysis of prostates from patients treated with radiation therapy showed an increased expression of BAX in prostate intraepithelial neoplasia versus normal glands in the same patient [112], and an increased expression of BAX was associated with poor outcomes [113], yet a mechanistic basis of increased BAX expression is unclear and the role of BAX in prostate cancer remains open.

An analysis of BAK expression by Western blotting showed no signal in prostate tissue extracts, yet immunohistochemical analysis identified BAK expression in the smooth muscle and the basal epithelial cells of prostate glands [114]. Expression of BAK was detected in prostate cancer cell lines and was increased in by estramustine, beta-lactone and other experimental therapeutics; yet, the mechanism(s) of increased BAK expression were not assessed [115-117]. Negative regulation of BAK by MAPK7/BMK1 phosphorylation at Y108 has been reported in several cancer cell lines [118]. BMK1 expression is increased in CRPC, however, since many receptor tyrosine kinases are activated by BMK1 in prostate cancer [119], the relative importance of BAK phosphorylation for CRPC compared to other BMK substrates is difficult to evaluate. Perhaps conditional knock-out experiments that delete BAK prior to castration, or knock-in experiments that replace WT-BAK with Y108deficient mutants may clarify the role of BAK in apoptosis induced by androgen ablation and the role of BAK phosphorylation in apoptosis resistance in advanced prostate cancer.

\subsection{BH3-Only Proteins}

BAD-Activity of BAD can be post-translationally controlled by phosphorylation that prevents interactions with the anti-apoptotic BCL-2 family proteins. Dephosphorylation by serine/threonine phosphatases restores BAD apoptotic activity [120-122]. Additionally, BAD expression could be silenced epigenetically via promoter methylation [111]. In a non-phosphorylated state BAD binds to and inactivates BCLX and BCL2, but cannot bind 
to MCL1. Design of the first-in-class BH3 mimetic drug ABT737 is mimicking the BH3 domain of BAD [123].

Increased expression of BAD was reported in prostate carcinoma and correlated with a longer time to biochemical relapse and overall survival [124,125].

Multiple signaling pathways induced by EGF, G-protein coupled receptors (GPCR) agonists, PMA, Galectin3, omega3- fatty acids, clusterin and $\alpha 2$-macroglobulin as well as by the loss of PTEN or hyperactive protein kinases have been connected to BAD phosphorylation in prostate cancer [126-134]. Numerous protein kinases including AKT1, MAPK1/ERK, RPS6KA1/RSK1, cAMP-activated protein kinase (PKA), PAK1, PRKCI/nPKC-iota, PRKCE/ nPKC-epsilon and PIM1 were reported to phosphorylate BAD in prostate cancer cells [135-137].

Phosphorylations at S75 and S99 (that correspond to S112 and S136 in mouse protein) create binding sites for 14-3-3 chaperons that sequester BAD in cytoplasm and prevent interactions with BCLX or BCL2 at mitochondria $[11,138,139]$. Phosphorylation at S118 (S155 in mice) in BH3 domain directly disrupts interaction with anti-apoptotic proteins.

Beside these three major phosphorylation sites, phosphorylation of S111 and S134 were also reported; however, their significance for apoptosis in prostate cancer cells has not been assessed [140].

BIM-is a BH3 only protein that can bind all anti-apoptotic proteins of the BCL-2 family and it also has a dynein binding motif that mediates binding to the cytoskeleton. A comprehensive review on BIM has been recently published [141]. BIM can be regulated both transcriptionally and post-translationally. At the transcriptional level, BIM mRNA levels are positively regulated by the transcription factors FOXO3, CEBPA, DDIT3/CHOP, and E2F1 and negatively regulated by the miRNA cluster miRNA-17-92. The opposing effects of cytokines and oxidative stress on BIM mRNA stability via heat-shock proteins have been reported [141]. Several forms of BIM are generated by alternative splicing including BIM-gamma expressed in prostate cancer cells [142]. At the post-translational level, BIM is regulated by phosphorylation, which have opposing effects on pro-apoptotic BIM function depending on the kinases involved and the sites of phosphorylation. Anti-apoptotic signals by MEK1/ERK/RSK1, PI3K/AKT1 and LYN kinases induce BIM phosphorylation that disrupts interactions with anti-apoptotic proteins and creates binding sites for ubiquitin ligases that stimulate its ubiquitination and subsequent proteasomal degradation $[120,143,144]$. In contrast, phosphorylation by PKA, MAPK8/JNK and MAPK14/p38 increases BIM apoptotic activity [141].

Elevated expression of BIM in prostate tumors has been reported [145]. BIM expression has been detected in prostate cancer cells, and modulation of BIM levels by cytotoxic and survival signals was connected with apoptosis in prostate cancer cells and in the prostate glands of $\mathrm{Pten}^{-/}$mice [146-148]. At the same time, a more nuanced role of BIM in apoptosis was proposed, when increased BIM expression had an anti-apoptotic effect that was reversed by phosphorylation that prompted interaction with BCLX and MCL1 in prostate cancer cells [145].

PUMA and NOXA-PUMA and NOXA are regulated at the transcriptional level by TP53 as well as by E2F1 [120,149]. Furthermore, transcription of NOXA can be epigenetically silenced via promoter methylation [150]. Unlike other BH3-only proteins, PUMA is only regulated transcriptionally [149]. NOXA, on the other hand, is also regulated post-translationally by ubiquitination which targets it for proteasomal degradation, and by phosphorylation at S13 position which blocks NOXA's pro-apoptotic activity [151].

PUMA and NOXA show reciprocal expression in prostate cancer cell lines. The immunohistochemical analysis of 51 normal prostates, 64 primary PCa and 30 CRPC showed significantly less NOXA expression in normal prostates when compared to hormone resistant and hormone sensitive cancers (that showed the highest expression). Patients with a higher NOXA levels had a shorter progression-free survival, and the opposite trend was noted for PUMA [152]. In another study PUMA was detected in six BPH samples but was undetectable in five Gleason grade 4, 5 prostate cancer samples. These contradictory reports call for additional studies with more stringent controls for the specificities of antibodies. 
In prostate cancer cells lines and in mouse prostates the activation of ER-beta induced PUMA expression and apoptosis via FOXO3 [153]. Other studies confirmed the role of increased expression of PUMA and NOXA in apoptosis induced by cytotoxic therapies in prostate cancer cells [154], yet more in depth studies are needed to reconcile tissue culture experiments and studies of clinical samples.

BIK-is a BH3-only protein that preferentially interacts with BCLX, BCL2L2/BCL-W and BCL2A1. At the transcriptional level, BIK can be upregulated by the transcription factor E2F-1. Post-translationally, pro-apoptotic activity of human BIK is increased by phosphorylation [120]. Broad institute gene expression database (https:// portals.broadinstitute. org / ccle/page?gene=BIK (accessed on 9 October 2020)) shows relatively high levels of BIK mRNA in prostate cancer cells, yet there are very few reports on the role of BIK in apoptosis regulation in prostate cancer cells $[155,156]$, and no data on BIK protein levels in prostate tumors.

BID-BID plays a unique role among other $\mathrm{BH} 3$ only proteins by connecting an extrinsic death receptor activated apoptotic pathway with an intrinsic mitochondrial pathway.

The pro-apoptotic function of full-length, inactive BID is exposed by the post-translational cleavage of BID by a several proteases (such as caspase- $8 /-2$ and granzyme B); thereby, forming an N-terminally truncated form of BID (tBID) that is targeted to the mitochondria. Post-cleavage $\mathrm{N}$-myristylation of BID promotes its targeting to the mitochondrial outer membrane which then further enhances BID's pro-apoptotic activity [101]. Upon targeting to the mitochondria, $\mathrm{BID}$ reportedly interacts and directly activates BAX and BAK [62,157] or according to more recent evidence binds anti-apoptotic BCLX and MCL1 and thus, shifts the balance toward apoptosis [158]. BID levels are regulated at the transcriptional level by the transcription factors TP53 [159] and HIF1 [160].

Immunohistochemical analysis of primary prostate cancers detected BID in normal prostate epithelium with higher immuno-scores then in advanced prostate cancers. In the T3 group higher BID scores were associated with longer recurrence-free survival. Analysis of the NCI panel of cancer cell lines showed lower BID levels in prostate cancer cells [161]. Several publications assessed death receptors signaling that was activated by FAS, TNF- $\alpha$ and TRAIL ligands in prostate cancer cells, and reported on the role of BID cleavage in defining an apoptosis decision [162-166]. The expression of C-terminal part of cleaved BID was sufficient to induce apoptosis in prostate cancer cells [164].

In summary, the evidence from the analysis of prostate cancer cell lines, transgenic mice and clinical samples support the role of the BCL-2 family proteins in apoptosis regulation in the prostate epithelium, yet our knowledge of specifics is limited. Experimental tools including inducible tissue-specific transgenes and single cell transcriptomics are now available to assess the role of BCL-2 family proteins in apoptosis that is induced by androgen ablation in the prostate epithelial cells. Several studies have looked into transcriptome changes in response to ADT [167-169] but none has reported changes in BCL-2 family gene expression. Perhaps, post-translational mechanisms are playing a leading role in regulating proteins of the BCL-2 family.

Experimental data from PCa cells provide compelling evidence on the regulation of MCL1, BAK and BH3-only proteins BAD and BIM by signal transduction pathways amenable for pharmacological targeting (Figure 2). The signal transduction pathways implicated in initiation and progression of the CRPC that target proteins of the BCL-2 family are described below. 


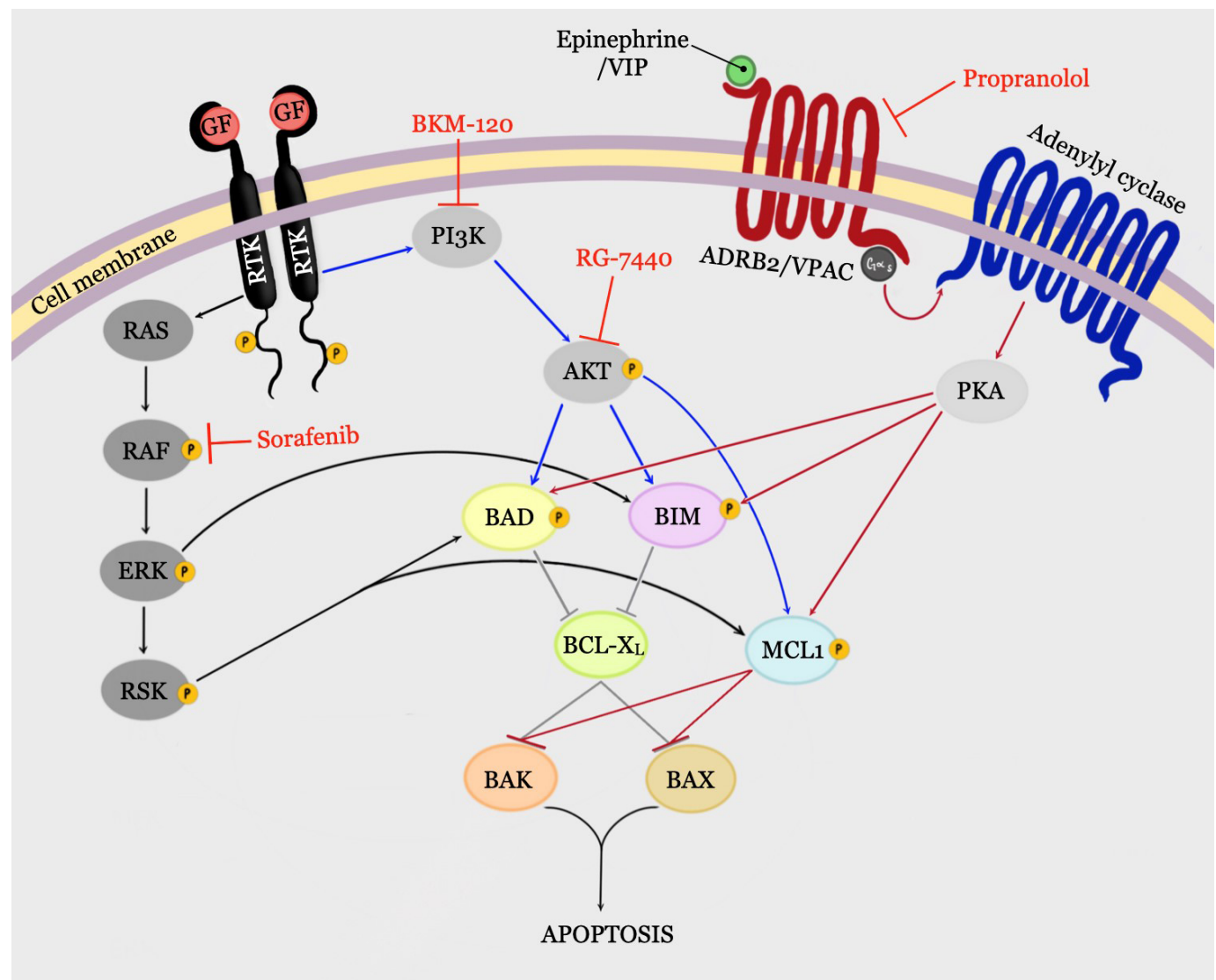

Figure 2. Apoptosis regulatory network in prostate cancer. MCL1 and BCLXL are dominant anti-apoptotic BCL2-family proteins in prostate cancer cells. RTK/ERK, PI3K/AKT and ADRB2/PKA signaling regulates transcription, translation and degradation of the anti-apoptotic protein MCL1 and pro-apoptotic functions of BIM and BAD. Inhibitors of these pathways are being tested in clinical trials.

\section{Signaling Pathways That Can Control BCL-2 Family Proteins 4.1. PI3K/AKT Signaling Pathway}

The PI3K/AKT is a conserved signal transduction pathway that controls cell growth, survival, angiogenesis, proliferation, metabolism, protein synthesis, and differentiation [170]. PI3K, a kinase belonging to the family of lipid kinases, is activated primarily by receptor tyrosine kinases (RTKs) at the cell membrane [11,138]. PI3K can also be activated by GPCRs, non-receptor tyrosine kinases and RAS oncogene [11]. Activated PI3K phosphorylates the $3^{\prime}$-hydroxyl group of phosphatidylinositol-4,5-diphosphate (PIP2); thereby, forming phosphatidylinositol-3,4,5triphosphate (PIP3). PIP3 recruits the two protein kinases containing pleckstrin homology $(\mathrm{PH})$ domain (serine/threonine kinases AKT and PDPK1/PDK1) to the membrane. AKT is then phosphorylated and activated by PDK1 and mTORC2 [11,138,171]. The phosphatase and tensin homolog deleted on chromosome 10 (PTEN) is a primary negative regulator of PI3K pathway that dephosphorylates PIP3 to PIP2, acting as a tumor suppressor [11,138].

The AKT phosphorylation creates binding sites for 14-3-3 chaperons that retain proteins in cytoplasm [172]. Direct targets of AKT include BAD and BIMEL $[173,174]$ that are involved in mitochondrial apoptosis; and PACS2 that controls interorganelle protein traffic and BID cleavage downstream of death receptors [175]. AKT and related SGK kinase can also phosphorylate and prevent nuclear entry of FOXO transcription factors; thus, inhibiting expression of FOXO-regulated pro-apoptotic proteins BIM, PUMA, FASL and TRADD [176-179]. The upregulation of MCL1 downstream of PI3K by transcriptional [180,181] and translational [182] mechanisms have been also reported. AKT phosphorylation inhibits GSK3 kinase that creates binding sites for ubiquitin ligases and targets 
MCL1 to degradation [183]. Thus, PI3K signaling may increase MCL1 protein levels by controlling transcription, translation and degradation.

Upregulation of the PI3K signaling pathway has been observed in $30-50 \%$ of prostate cancers $[4,11,12,138,184]$. The inactivation of PTEN, is the most common alteration resulting in overactivation of the PI3K pathway. Inactive PTEN can result from deletions or more commonly from mutations in PTEN [138]. Mice with prostate-targeted PTEN knockout show increased PI3K/AKT activation and developed prostate cancer [185].The activation of PI3K pathway could also occur due to overexpression or activating mutations of AKT or PI3K [11].

In PCa cells active PI3K/AKT pathway, inhibited the mitochondrial apoptosis by phosphorylating BAD [130] and by inhibiting TRAIL-induced apoptosis upstream of BID cleavage by an undefined mechanism [162] (Figure 2).

\subsection{RAS/ERK Signaling Pathway}

The activation of the RTK/RAS/ERK pathway by a wide range of extracellular stimuli is understood in detail. The RAS/ERK pathway induces phosphorylation of downstream substrates by the extracellular signal-regulated kinases (ERKs) that control proliferation, survival, differentiation, angiogenesis, motility and invasiveness [186]. Active ERKs also phosphorylate and activate the RSK family kinases that in turn phosphorylate a variety of cytoplasmic and nuclear substrates including the BH3-only proteins BIM and BAD, the transcription factor CREB, and the vasodilator-stimulated phosphoprotein (VASP) that controls cytoskeletal assembly and cell survival (Figure 2) [187-189].

Although rarely found mutated, activation of the RAS/ERK signaling pathway correlates with an increased Gleason score, AR-independence, metastasis and poor prognosis $[13,186,190,191]$. Thus, PCa patients who did not respond to ADT were found to have high levels of phospho-ERK [190]. Over the past 20 years, data linking activation of ERK signaling to PCa progression and therapy resistance has been consistently reported [190-193]. Using Nkx3.1;Pten mutant mice, which resemble main characteristics of CRPC, it has been demonstrated that AKT and ERK signaling pathways are active in androgen independent lesions and act synergistically to promote CRPC [194]. In prostate cancer cells, the activation of RAS/ERK signaling inhibited apoptosis by phosphorylating BAD [126,131,137] and by suppressing BIM expression [148] (Figure 2). Recent publications connected activation of FGFR with RAS/ERK and an inhibitor of differentiation (ID1) transcription factor signaling that played a major role in CRPC progression independently from AR axis $[17,195]$.

\subsection{GPCR/PKA Signaling}

In addition to PI3K/AKT and RAS/ERK signaling, the new evidence has emerged that connected signaling by GPCR/PKA module to prostate cancer progression and therapy resistance via inhibition of apoptosis in tumor epithelial cells and stem cells, and increased angiogenesis [21,196-198].

\subsubsection{VIP/PKA Signaling}

The VIP is a neuropeptide widely distributed in the peripheral and central nervous systems as well as endocrine-paracrine cells $[199,200]$. Nerves supplying VIP are found in several organs including the prostate gland [200]. VIP binds to and activates VPACs receptors of the GPCRs family and PKA. VIP/PKA signaling protects the PCa cells from apoptosis by inducing BAD phosphorylation $[130,196]$. VIP was also shown to transactivate AR in a PKA-dependent manner [201].

\subsubsection{ADRB2/PKA Signaling}

$\beta$-adrenergic receptors (ADRBs), are seven transmembrane GPCRs activated by the catecholamines epinephrine (Epi) and norepinephrine (NE) released by the sympathetic nervous system (SNS) in response to physical and psychoemotional stress [197,198]. Epi is produced by chromaffin cells while NE is produced by adrenergic nerves that innervate 
most of the major organs including the prostate gland [198]. Activation of ADRB2 and downstream PKA by Epi and NE was found to be important for both normal prostate development and prostate carcinogenesis [197,198].

The prostate is a highly innervated organ with majority of the nerves found in the peripheral zone of the gland. In addition to that, the paraganglia, containing chromaffin cells that produce Epi, are located close to sympathetic nerves in the prostate. Secretions of luminal cells are facilitated by adrenergic nerve firing that activates the ADRBs [198]. ADRB2 is the predominant adrenergic receptor subtype in luminal cells of the human prostate while both ADRB2 and ADRB3 are found in prostate stromal cells [197,198].

The mechanisms of ADRB2 and VPAC GPCR signaling in PCa cell lines are similar. Ligand binding induces conformational change in GPCR that increases its GDP/GTP exchange activity toward the $\mathrm{G} \alpha$ subunit of heterotrimeric G-proteins associated with receptors. In GTP-bound form $\mathrm{G} \alpha$ binds to and activates adenylyl cyclase, that produce cAMP. cAMP binds to the regulatory subunit of PKA, causing the release of active PKA's catalytic subunit. PKA's catalytic subunit can then phosphorylate several downstream targets including BAD, MCL1, VASP and transcription factor CREB; and also modulate activation of PI3K/AKT and RAS/ERK pathways [21,198]. The ability of GPCR/PKA signaling to inactivate BAD and stabilize MCL1 results in more efficient inhibition of apoptosis compared to pathways that target just one molecule of the apoptotic machinery (Figure 2) [21].

Several recent studies demonstrated a connection between the activation of ADRB2/PKA pathway and therapy resistance in preclinical models of prostate cancer. Additionally, retrospective studies show that the use of beta-blockers is associated with the increased survival of patients with melanomas [202,203] and ovarian cancer [204], as well as prevention of metastasis and improvement of relapse-free survival of breast cancer patients [205]. In PCa the use of beta-blockers use has been linked with decreased metastasis, [206] decreased mortality in patients with high-risk or metastatic disease, [207] and improved survival in ADT-treated patients [208]. One such beta-blocker, propranolol, showed protective effect in several cancers including PCa [209]. Propranolol (a non-selective antagonist of ADRB1 and ADRB2) is clinically approved for the treatments of hypertension, cardiovascular diseases, anxiety and tremor [209,210] and could be repurposed for PCa treatment [21].

\section{Clinical Trials of Drugs Targeting Anti-Apoptotic Signaling in PCa}

In August 2020, 736 clinical trials of drugs targeting signaling pathways connected with the apoptosis inhibition in CRPC (RTK, RAF, and PI3K/AKT/MTOR) were registered in clinicaltrials.gov database. Numerous phase I studies assessed the dosage and safety of those drugs, yet we decided to focus on the results of 53 phase II/III trials published in peer-reviewed journals (Table 1). These clinical trials can be divided into four large groups: RTK inhibitors, VEGFR inhibitors, RAF kinase inhibitors and PI3K pathway inhibitors.

Activation of the PI3K/AKT/MTOR pathway is very common among CRPC patients, therefore, targeting components of this pathway could test the PI3K pathway contribution to therapy resistance in CRPC. A phase II study of the pan-AKT inhibitor ipatasertib showed a prolonged radiographic progression-free survival (rPFS) compared to a placebo particularly in PTEN-negative patients. The trend toward a longer overall survival and a time-to-PSA progression in the ipatasertib group was noted; yet, it did not reach a statistical significance [211]. Phase II trial of PI3K inhibitor buparlisib did not show prolongation of PFS when compared to historic data, and reported a 5-fold decline in plasma concentration of buparlisib when administered with enzalutamide [212]. Likewise, phase II trials with the pan-class I PI3K inhibitor PX-866 reported no resistance reversal when administered with abiraterone acetate in recurrent or mCRPC [213]. No phase III trials with anti-PI3K agents have been conducted so far, and published phase II trials did not include control groups, therefore, no conclusion on clinical benefits of targeting PI3K in CRPC can be made. Several clinical trials testing PI3K inhibitors are ongoing, including two phase I studies 
with AZD8186 (NCT03218826), (NCT01884285), and a phase II trial of dual inhibitor of class I PI3K and MTOR LY3023414 (NCT02407054), in advanced/metastatic PCa and CRPC.

Inhibitors of MTOR were tested in several phase II trials as single agents and in combination with other therapies for CRPC [214-218]. Comparison of pre-treatment and post-treatment biopsies in patients who received subtoxic dose of MTOR inhibitor MLN0128, detected a decrease in rpS6, but no change in pS473AKT or 4EBP1 [214]. None of the nine patients in this study showed a decrease in PSA or a circulated tumor cell (CTC) count. Lack of clinical activity and a transient CTC decline was reported in earlier phase II trials of MTOR inhibitor temsirolimus, yet phosphorylation of MTOR downstream targets was not evaluated in these studies [215-217]. Lack of clinical activity was also reported for everolimus [219], although the trend to a longer PFS was observed for patients with PTEN deletion [220]. Since activation of AR axis was connected with an inhibition of PI3K/MTOR signaling, a combination of MTOR inhibition with second generation AR inhibitors was suggested. Still, combining everolimus with bicalutamide proved ineffective in CRPC patients that had been previously treated with bicalutamide [221]. However, in the bicalutamide-naïve CRPC group, a higher percentage of patients showed a PSA decline compared to historical data for bicalutamide monotherapy [222]. Inhibiting MTOR (everolimus) together with EGFR (gefitinib) resulted in a rapid increase in PSA in 13/37 CRPC patients which then declined upon treatment discontinuation [223]. No evident clinical benefits were observed when MTOR inhibitor ridaforolimus was combined with taxane in CRPC patients [224]. In summary, phase II studies failed to demonstrate clinical efficacy of MTOR inhibitors that would justify phase III trials.

Overall, compared to PI3K and MTOR inhibitors, pan-AKT inhibitors demonstrated the best clinical efficacy against CRPC, particularly in PTEN-deficient tumors. These encouraging results highlight the importance of patient pre-screening to select patients with active PI3K pathway for clinical trials of inhibitors that target the PI3K pathway and also of the need to confirm the inhibition of the intended target by analyzing the relevant biomarkers in post-treatment biopsies.

Activation of receptor tyrosine kinases (RTK) was connected with CRPC, and several RTK inhibitors showed clinically meaningful activity in CRPC. The pan-RTK inhibitor cabozantinib (targeting MET, RET, AXL, VEGFR2, FLT3, and KIT) [225] demonstrated clinical activity in the CRPC phase II trials as indicated by the improved PFS (23.9 vs. 5.9 weeks [226] and 5.5 vs. 1.4 months [227]), pain relief, bone scans, analgesic use, measurable disease, and bone biomarkers when compared to a placebo [228]. However, phase III trials compared cabozantinib to prednisone or mitoxantrone-prednisone in heavily treated CRPC patients did not demonstrate significant improvements in OS or PSA outcomes despite improved PFS [229] or improve pain relief [230]. Unlike cabozantinib, the EGFR family inhibitor afatinib, did not result in any progression-free CRPC patients or PSA response in a phase II study [231].

Sunitinib (inhibitor of KIT, FLK1/KDR and PDGFR-beta RTKs) had minimal impact on PSA levels in a chemotherapy-naïve and docetaxel-treated CRPC patients, and had discordant PSA and radiographic responses. The target inhibition assessment revealed reductions in VEGFR2 and PDGFaa upon sunitinib treatment; however, PFS or OS was not assessed [232]. The EGFR inhibitor, gefitinib did not show objective responses in CRPC as a single agent or in combination with androgen-targeting therapy or docetaxel [233-239], while lapatinib, an EGFR and HER2 inhibitor, decreased blood PSA when compared with historic controls in CRPC patients [240]. In phase II studies of EGFR tyrosine kinase inhibitor erlotinib, PSA decreases were observed in CRPC patients, yet no improvements in OS or PFS were reported [241-243]. Additionally, phase II studies showed that combining the VEGFR-2/EGFR tyrosine kinase inhibitor vandetanib with bicalutamide or docetaxel/prednisolone did not have superior activity over bicalutamide or docetaxel/prednisolone monotherapy in mCRPC patients [244,245]. However, in metastatic CRPC, combining cetuximab (a monoclonal antibody directed against EGFR) with docetaxel increased PFS in patients that had overexpressed EGFR and persistent PTEN 
expression [246]. In another trial, cetuximab combined with doxorubicin caused minimal PSA declines, yet improved survival when compared to historic control groups [247]. Combining cetuximab with mitoxantrone/prednisone in unselected docetaxel-treated CRPC patients showed a shorter median time to progression comparing to patients who did not receive cetuximab ( 4.9 vs. 6.6 months); however, in cetuximab group in patients who developed a rash, time to progression was significantly longer (10.3 months vs. 2.8 months, $p=0.004)$ [248].

The HER2 dimerization inhibitor pertuzumab did not result in objective responses, but improved survival when compared to historic control groups [249]. Trastuzumab, a humanized monoclonal antibody directed against HER2, demonstrated poor efficacy [250,251], that could be due to low levels of HER2 expression in prostate cancer [252].

To sum up, based on results of trials that included control groups, broad specificity RTK inhibitors (e.g., cabozantinib) and EGFR-targeting monoclonal antibodies (e.g., cetux$\mathrm{imab}$ ) showed the most clinically meaningful activity in CRPC patients by extending PFS based on bone scans and pain symptoms, yet failed to demonstrate a statistically significant increase in OS. Cetuximab (antibodies against EGFR) and trastuzumab (antibodies against HER2 that inhibit ligand-induced heterodimerization with other HER family members) showed a tendency to increased survival when compared to historic data.

Since neovascularization is required for growth of solid tumors [253], several VEGFR tyrosine kinase inhibitors have been tested in the clinic (Table 1). Phase II/III trials that included control groups showed that targeting angiogenesis by blocking all VEGF receptors (VEGFR-1, -2, -3) or VEGF-A improved PFS in CRPC, but failed to increase OS. Comparison with currently accepted protocols for CRPC treatments showed increased toxicity of VEGFR but no significant survival benefits [254].

Targeting RAF kinases has been tested in phase II trials in CRPC patients. In earlier trial, abrogation of RAF1 by the anti-sense oligonucleotide ISIS 5132 did not induce any objective or PSA responses in CRPC; although, tumor biopsies were not taken to evaluate the target knockdown [255]. A phase II trial of sorafenib (RAF and VEGF-2/PDGFRbeta kinase inhibitor) suggested clinical benefits for CRPC patients with metastatic bone lesions [256,257]. The analysis of bone marrow biopsies did not show a significant decrease of pERK (a downstream target of RAF kinases), but showed pERK reduction in one patient with improved bone scan lesions post-sorafenib treatment. However, biopsies were taken only after sorafenib treatments, thus, no comparisons in the same patient were possible [256]. Despite reported benefits and low toxicity in phase II trials, no phase III trials with RAF-targeting agents have been conducted to provide reliable information on the clinical efficacy of RAF kinase inhibitors in CRPC.

At present, there are no completed clinical trials targeting components of the RAS/ERK pathway (other than RAF kinases), the ADRB2/PKA pathway, or death receptor signaling. However, there are currently ongoing trials testing the efficacy of the MEK inhibitor trametinib in CRPC alone (NCT02881242) and with/without AR inhibition (NCT01990196). Clinical trials that examine the ADRB2 antagonists propranolol (NCT03152786) and carvedilol (NCT02944201) in primary PCa are ongoing; however, no clinical studies have been reported in CRPC patients.

In summary, at present the strongest effects on PFS are achieved with the broad specificity RTK inhibitor cabozantinib, EGFR-targeting monoclonal antibody cetuximab in PTEN positive tumors, and the pan-AKT inhibitor ipatasertib. Importantly, more pronounced improvements with AKT and MTOR inhibitors were observed in patients with PTEN-negative tumors (where PI3K pathway is constitutively active). Effects on overall survival were modest or not yet available. Although several phase II studies tested PI3K, MTOR and RAF-1 inhibitors, none of those studies provided reliable information on clinical efficacy of those drugs and future studies with control groups are needed to prove or disprove their efficacy in CRPC.

These rather disappointing results are a call to rethink the way clinical trials of signal transduction inhibitors are designed. Patient selection based on tumor molecular profiling; 
monitoring inhibition of target molecules and downstream pathways along with changes in signaling network topology, apoptosis and proliferation before and during treatment are just a few examples of the "to do list" for future clinical trials. New tools for transcriptome, proteome and phospho-proteome analysis at the single cell level are needed to provide meaningful data for the clinical evaluation of inhibitors of signaling pathways that control apoptosis in CRPC.

Table 1. Clinical trials of drugs targeting anti-apoptotic signaling in prostate cancer (PCa).

\begin{tabular}{|c|c|c|c|c|}
\hline Agent & Target(s) & Population & Phase & Outcome \\
\hline $\begin{array}{l}\text { Tpatasertib } \\
\text { (GDC-0068, } \\
\text { RG-7440)+ } \\
\text { abiraterone }\end{array}$ & $\begin{array}{l}\text { All AKT } \\
\text { isoforms + } \\
\text { AR }\end{array}$ & $\begin{array}{l}\text { PTEN-negative } \\
\text { mCRPC }\end{array}$ & Phase II & $\begin{array}{l}\text { - Improved rPFS ( } 8.18 \mathrm{mo} \text { ( } 400 \mathrm{mg} \text { ipatasertib) and } \\
8.31 \mathrm{mo}(200 \mathrm{mg} \text { ipatasertib) vs. } 6.37 \text { mo for placebo) } \\
\text { [212] }\end{array}$ \\
\hline $\begin{array}{l}\text { MLN0128 } \\
\text { (Sapanisertib, } \\
\text { INK 128) }\end{array}$ & $\begin{array}{l}\text { TORC1 } \\
\text { and } \\
\text { TORC2 }\end{array}$ & $\begin{array}{l}\text { mCRPC-after } \\
\text { abiraterone } \\
\text { acetate and/or } \\
\text { enzalutamide }\end{array}$ & Phase II & $\begin{array}{l}\text { - PSA rise on treatment in all patients (median, } \\
159 \% \text { increase from baseline); PSA declined } \\
\text { immediately in } 4 \text { patients upon drug discontinuation } \\
\text { [215] }\end{array}$ \\
\hline $\begin{array}{l}\text { Temsirolimus } \\
\text { (Torisel, } \\
\text { CCI-779) }\end{array}$ & MTOR & mCRPC & Phase II & $\begin{array}{l}\text { - } \quad \geq 30 \% \text { PSA decline (1 patient). } \\
\text { - } \quad \text { Median PFS: } 1.9 \text { mo; median OS: } 8.8 \text { mo [216] }\end{array}$ \\
\hline $\begin{array}{l}\text { Everolimus } \\
\text { (RAD001, } \\
\text { Afinitor, } \\
\text { Zortress) }\end{array}$ & MTOR & $\begin{array}{l}\text { chemotherapy- } \\
\text { naïve mCRPC } \\
\text { patients }\end{array}$ & Phase II & $\begin{array}{ll}\text { - } & \geq 50 \% \text { PSA response (5\% of patients), } \geq 30 \% \\
\text { PSA decline (11\% patients) } \\
\text { - } \\
\text { Improved PFS and response associated with } \\
\text { PTEN deletion [221] }\end{array}$ \\
\hline \multirow[t]{2}{*}{$\begin{array}{l}\text { Everolimus + } \\
\text { bicalutamide }\end{array}$} & \multirow[t]{2}{*}{$\begin{array}{l}\text { MTOR } \\
+ \text { AR }\end{array}$} & $\begin{array}{l}\text { CRPC- } \\
\text { previously treated } \\
\text { with bicalutamide }\end{array}$ & Phase II & $\begin{array}{l}\text { - } 2 / 36 \text { patients had a confirmed } \geq 50 \% \text { PSA } \\
\text { reduction; } 9 / 36 \text { patients had stable disease (SD) } \\
\text { by PSA levels (no longer than } 6 \text { mo) } \\
\text { Did not reach primary endpoint of improved } \\
\text { response compared to historic bicalutamide } \\
\text { results [222] }\end{array}$ \\
\hline & & $\begin{array}{l}\text { Bicalutamide- } \\
\text { naïve } \\
\text { CRPC }\end{array}$ & Phase II & - $\quad \geq 30 \%$ PSA decline in $75 \%$ of patients [223]. \\
\hline $\begin{array}{l}\text { Everolimus + } \\
\text { carboplatin + } \\
\text { prednisone }\end{array}$ & $\begin{array}{l}\text { MTOR + } \\
\text { DNA } \\
\text { replication } \\
+ \text { GR }\end{array}$ & $\begin{array}{l}\text { mCRPC } \\
\text { pretreated with } \\
\text { docetaxel }\end{array}$ & Phase II & $\begin{array}{l}\text { - Median time to progression: } 2.5 \mathrm{mo} \text {; Median OS: } \\
\text { - } 8 / 5 \mathrm{mo} \text { patients with positive nuclear } \\
\text { phosphorylated pAKT progressed within } 9 \\
\text { weeks while } 2 / 10 \text { patients with negative } \\
\text { staining continued without progression for } 30 \\
\text { and } 48 \text { weeks [220] }\end{array}$ \\
\hline $\begin{array}{l}\text { Buparlisib } \\
\text { (BKM-120) }+ \\
\text { enzalutamide }\end{array}$ & $\begin{array}{l}\text { Class I } \\
\text { PI3K + AR }\end{array}$ & $\begin{array}{l}\mathrm{mCRPC} \\
\text { progressing on or } \\
\text { are not candidates } \\
\text { for docetaxel }\end{array}$ & Phase II & $\begin{array}{l}6 \text { mo median PFS: } 1.9 \text { mo (buparlisib alone) vs. } \\
3.5 \text { mo (buparlisib/enzalutamide) } \\
\text { Median OS of all subjects: } 10.6 \text { mo (similar } \\
\text { buparlisib or buparlisib + enzalutamide } \\
\text { groups). } \\
\text { 1-year survival rate: } 35.3 \% \text { (buparlisib) and } \\
\text { 53.8\% (buparlisib/enzalutamide) } \\
\text { PSA declined in } 23 \% \text { of patients (not } \geq 50 \% \text { ); } \\
\text { decline rates did not differ in with/without } \\
\text { enzalutamide } \\
\text { - No radiographic responses [213] }\end{array}$ \\
\hline $\begin{array}{l}\text { PX-866+/- } \\
\text { abiraterone } \\
\text { acetate }\end{array}$ & $\begin{array}{l}\text { Class I } \\
\text { PI3K + AR }\end{array}$ & $\begin{array}{l}\text { recurrent or } \\
\text { metastatic CRPC }\end{array}$ & Phase II & $\begin{array}{l}\text { - With single agent PX- } 866,33 \% \text { were } \\
\text { progression-free at } 12 \text { weeks, } 2 \text { partial OR, and } \\
1 \text { confirmed PSA response } \\
\text { - Combination showed no evidence of castration } \\
\text { resistance reversal ( } 24 \% \text { patients were } \\
\text { progression-free at } 12 \text { weeks; no OR or PSA } \\
\text { response). } \\
\text { No correlation between PTEN status and } \\
\text { response [214] }\end{array}$ \\
\hline
\end{tabular}


Table 1. Cont

\begin{tabular}{|c|c|c|c|c|}
\hline Agent & Target(s) & Population & Phase & Outcome \\
\hline \multirow[b]{2}{*}{$\begin{array}{l}\text { Temsirolimus } \\
\text { (Torisel, } \\
\text { CCI-779) }\end{array}$} & \multirow[b]{2}{*}{ MTOR } & $\begin{array}{l}\text { Docetaxel-treated } \\
\text { CRPC patients }\end{array}$ & \multirow[b]{2}{*}{ Phase II } & $\begin{array}{l}\text { - Median time to treatment failure: } 24.3 \text { weeks; } \\
\text { - } \quad \text { Median time to PSA progrial tumor response (4.8\%); } 1 \text { PSA response } \\
(4.8 \%) \text { [217]. }\end{array}$ \\
\hline & & $\begin{array}{l}\text { Chemotherapy- } \\
\text { naïve } \\
\text { CRPC }\end{array}$ & & $\begin{array}{l}\text { Partial response (PR): } 2 / 15 \text { patients; SD: } 8 / 15 \text {; } \\
\text { OR: } 2 / 15 ; \text { Overall clinical benefit (OR+SD): } \\
\text { 10/15. } \\
\text { Median time to radiographic disease } \\
\text { progression: } 2 \text { mo } \\
\text { - Any PSA decline: } 4 / 14 \text { four patients }(28.5 \%) ; \\
\text { 1 patient (7\%) had }>50 \% \text { PSA decline. } \\
\text { Median time to PSA progression: } 2 \text { mo } \\
\text { - Median OS: } 13 \text { mo; } 3 \text { patients remained alive at } \\
\text { the data cutoff for an OS of } 14 \% \text { at } 4 \text { years [218]. }\end{array}$ \\
\hline $\begin{array}{l}\text { Ridaforolimus } \\
\text { (AP23573 } \\
\text { MK8669) }\end{array}$ & MTOR & $\begin{array}{l}\text { Taxane-treated } \\
\text { CRPC patients }\end{array}$ & Phase II & $\begin{array}{l}\text { - No OR; } 47.4 \% \text { of patients had SD as their best } \\
\text { response; } 21.1 \% \text { had SD as their best overall } \\
\text { PSA response. } \\
\text { - Median time to progression: } 28 \text { days [225] }\end{array}$ \\
\hline $\begin{array}{l}\text { Ridaforolimus + } \\
\text { bicalutamide }\end{array}$ & $\begin{array}{l}\text { MTOR + } \\
\text { AR }\end{array}$ & $\begin{array}{l}\text { Asymptomaticm } \\
\text { CRPC patients }\end{array}$ & Phase II & $\begin{array}{l}\text { Dose reductions were required in } 7 \text { patients. } \\
3 / 11 \text { patients experienced dose-limited toxicity } \\
\text { leading to }<75 \% \text { of planned ridaforolimus dose } \\
\text { during the first } 35 \text { days of study treatment. } \\
\text { The pharmacokinetic results showed no } \\
\text { differences in exposures to ridaforolimus with } \\
\text { and without concomitant bicalutamide } \\
\text { administration [219]. }\end{array}$ \\
\hline $\begin{array}{l}\text { Everolimus + } \\
\text { gefitinib (Iressa, } \\
\text { ZD 1839) }\end{array}$ & $\begin{array}{l}\text { MTOR + } \\
\text { EGFR }\end{array}$ & CRPC & $\begin{array}{l}\text { Phase } \\
\text { I/II }\end{array}$ & $\begin{array}{l}\text { - } 67 \% \text { discontinued treatment before evaluation } \\
\text { due to progression (evidenced by PSA levels or } \\
\text { imaging or because of a grade } 2 \text { or higher } \\
\text { toxicity). } \\
\text { - } 35 \% \text { rapidly elevated PSA which declined upon } \\
\text { treatment discontinuation. } \\
\text { Fluorodeoxyglucose positron emission } \\
\text { tomography } 24 \text { to } 72 \text { h after the initiation of } \\
\text { treatment showed a decrease in the } \\
\text { standardized uptake value consistent with } \\
\text { MTOR inhibition in } 27 \text { of } 33 \text { evaluable patients } \\
\text { (82\%); there was a corresponding rise in PSA in } \\
20 \text { of these } 27 \text { patients }(74 \%) \text { [224]. }\end{array}$ \\
\hline \multirow{4}{*}{$\begin{array}{l}\text { cabozantinib } \\
\text { (Cabometyx, } \\
\text { Cometriq, } \\
\text { Cabozanix, } \\
\text { BMS-907351, } \\
\text { XL184) }\end{array}$} & \multirow{4}{*}{ RTK } & $\begin{array}{l}\text { advanced, } \\
\text { recurrent or } \\
\text { metastatic cancers }\end{array}$ & Phase II & $\begin{array}{l}\text { - CRPC patients had largest PFS (median, } 5.5 \text { mo } \\
\text { vs. } 1.4 \text { mo for placebo) [228] }\end{array}$ \\
\hline & & & & $\begin{array}{l}\text { - Improved PFS (median, } 23.9 \text { weeks with } \\
\text { cabozantinib vs. } 5.9 \text { weeks with placebo) [227]. }\end{array}$ \\
\hline & & CRPC & Phase II & $\begin{array}{l}\text { - clinically meaningful pain relief: } 57 \% \text { of } \\
\text { patients; reduction or discontinuation of } \\
\text { narcotic analgesics: } 55 \% \text {; bone scan response } \\
\text { improvement: } 73 \%(100 \mathrm{mg} \text { ) and } 45 \%(40 \mathrm{mg}) \text {; } \\
\text { reductions in measurable soft tissue disease: } \\
80 \% \text { and } 79 \% \text {, respectively. } \\
\text { Median OS: } 12.1 \mathrm{mo}(100-\mathrm{mg}) \text { and } 9.1 \mathrm{mo} \\
\text { (40-mg) [229]. }\end{array}$ \\
\hline & & $\begin{array}{l}\text { MCRPC- } \\
\text { previously treated } \\
\text { with docetaxel } \\
\text { and abiraterone } \\
\text { and/or } \\
\text { enzalutamide }\end{array}$ & $\begin{array}{l}\text { Phase } \\
\text { III }\end{array}$ & $\begin{array}{l}\text { - Improved OS (11.0 mo with cabozantinib vs. } \\
9.8 \text { mo with prednisone) and rPFS (median, } 5.6 \\
\text { v } 2.8 \text { mo) compared to prednisone } \\
\text { - No improvement in PSA outcomes compared to } \\
\text { prednisone [230] }\end{array}$ \\
\hline
\end{tabular}


Table 1. Cont.

\begin{tabular}{|c|c|c|c|c|}
\hline Agent & Target(s) & Population & Phase & Outcome \\
\hline $\begin{array}{l}\text { Sunitinib } \\
\text { (Sutent, } \\
\text { SU11248, } \\
\text { SU011248) }\end{array}$ & RTK & CRPC & Phase II & $\begin{array}{l}\text { - } 1 \text { confirmed 50\% PSA decline in } \\
\text { chemotherapy-naïve group (A) and one in } \\
\text { docetaxel-resistant CRPC groups (B). } 8 \text { and } \\
12 \text { patients in groups A and B, respectively had } \\
\text { stable PSA upon treatment. } \\
\text { Improvements in imaging were seen } \\
\text { post-treatment despite lack of PSA declines } \\
\text { [233]. }\end{array}$ \\
\hline $\begin{array}{l}\text { Afatinib } \\
\text { (Gilotrif, BIBW } \\
\text { 2992 MA2) }\end{array}$ & EGFR & CRPC & Phase II & - limited anti-tumor activity [232] \\
\hline \multirow{4}{*}{$\begin{array}{l}\text { Gefitinib } \\
\text { (ZD1839, Iressa) }\end{array}$} & \multirow{4}{*}{ EGFR } & $\begin{array}{l}\text { mCRPC } \\
\text { progressing on } \\
\text { LHRH analog + } \\
\text { antiandrogen } \\
\text { (bicalutamide or } \\
\text { flutamide). }\end{array}$ & Phase II & - No PSA or objective response in any patient [236]. \\
\hline & & $\mathrm{nmCRPC}$ & Phase II & $\begin{array}{l}\text { - None of the evaluable patients had a PSA } \\
\text { response [238]. }\end{array}$ \\
\hline & & $\begin{array}{l}\text { Chemotherapy- } \\
\text { naïve } \\
\text { CRPC }\end{array}$ & Phase II & $\begin{array}{l}\text { - No patient had PSA or objective measurable } \\
\text { response; } 14.3 \% \text { of patients had stable PSA } \\
\text { ( } 1 \text { patient at } 250 \mathrm{mg} \text { gefitinib and } 4 \text { at } 500 \mathrm{mg} \text { ); } \\
14.3 \% \text { had a best response of SD (duration, } 2.5 \text { to } \\
16.8 \mathrm{mo} \text { ). } \\
\text { No significant effect on the rate of PSA increase } \\
\text { [234]. }\end{array}$ \\
\hline & & CRPC & Phase II & $\begin{array}{l}\text { - } 1 \text { patient had a confirmed } 50 \% \text { PSA response. } \\
\text { Median time to progression: } 28 \text { days. } \\
\text { Majority of patients had a stable performance } \\
\text { status while on study. } 13 / 51 \text { patients required a } \\
\text { dose reduction; } 9 / 51 \text { patients withdrew due to } \\
\text { an adverse event [259]. }\end{array}$ \\
\hline $\begin{array}{l}\text { Gefitinib + } \\
\text { docetaxel }\end{array}$ & $\begin{array}{l}\text { EGFR + } \\
\text { tubulin }\end{array}$ & CRPC & Phase II & $\begin{array}{l}\text { Response rate and duration were consistent with } \\
\text { those of docetaxel monotherapy [237] }\end{array}$ \\
\hline $\begin{array}{l}\text { Gefitinib + } \\
\text { prednisone }\end{array}$ & EGFR + GR & CRPC & Phase II & $\begin{array}{l}\text { - At median follow-up time of } 29 \mathrm{mo}, 77 \text { patients } \\
\text { progressed and } 51 \text { died. } \\
\text { PSA response in } 15.8 \% \text { (combination) and } 11.4 \% \\
\text { patients (prednisone + placebo) } \\
\text { Time to progression: median, } 4.0 \text { mo } \\
\text { (prednisone + gefitinib); } 4.5 \text { mo (prednisone + } \\
\text { placebo); survival: median, 26.5 mo (prednisone } \\
\text { + gefitinib); } 20.5 \text { mo (prednisone + placebo) } \\
\text { [240]. }\end{array}$ \\
\hline $\begin{array}{l}\text { Gefitinib + } \\
\text { antiandrogen + } \\
\text { LH-RH } \\
\text { analogue }\end{array}$ & $\begin{array}{l}\text { EGFR + AR } \\
+ \text { GnRH } \\
\text { receptor }\end{array}$ & CRPC & Phase II & $\begin{array}{l}\text { - Gefitinib treatment did not result in any objective } \\
\text { response (PSA or OR). Median time to progression } \\
\text { was } 70 \text { days. Median OS was } 293 \text { days [235]. }\end{array}$ \\
\hline $\begin{array}{l}\text { Vandetanib } \\
\text { (ZACTIMA) + } \\
\text { bicalutamide }\end{array}$ & $\begin{array}{l}\text { VEGFR2/ } \\
\text { EGFR + AR }\end{array}$ & $\begin{array}{l}\text { Chemotherapy- } \\
\text { naïve mCRPC } \\
\text { (rising PSA on } \\
\text { ADT and } \\
\text { minimally } \\
\text { symptomatic) }\end{array}$ & Phase II & $\begin{array}{l}\text { PSA response: } 18 \% \text { in arm A (vandetanib + } \\
\text { bicalutamide) and } 19 \% \text { arm B (bicalutamide). } \\
\text { Time to PSA progression: } 3.16 \text { mo (Arm A) and } \\
3.09 \text { mo (Arm B) [245]. }\end{array}$ \\
\hline Vandetanib & $\begin{array}{l}\text { VEGFR2/ } \\
\text { EGFR }\end{array}$ & $\mathrm{mCRPC}$ & Phase II & $\begin{array}{l}\text { - } \quad \text { PSA response: } 67 \% \text { patients (placebo + DP) vs. } \\
40 \% \text { (vandetanib + DP) } \\
\text { - } 65 \% \text { experienced progression events (disease } \\
\text { progression or death from any cause) in } \\
\text { vandetanib + DP vs. } 60 \% \text { in placebo + DP [246]. }\end{array}$ \\
\hline
\end{tabular}


Table 1. Cont

\begin{tabular}{|c|c|c|c|c|}
\hline Agent & Target(s) & Population & Phase & $\begin{array}{l}\text { Outcome } \\
\end{array}$ \\
\hline cetuximab & EGFR & mCRPC & $\begin{array}{l}\text { Phase } \\
\text { Ib/IIa }\end{array}$ & $\begin{array}{l}\text { - } \quad \text { SD in } 65 \% \text { patients with bone disease and } 61 \% \\
\text { patients with lymph node disease } \\
\text { - PSA declines: modest in the } 36 \text { patients; } 1 \\
\text { patient }(2.7 \%) \text { had an } 80 \% \text { decline from baseline, } \\
2(5.6 \%) \text { had }>50 \% \text { to }<80 \% \text { decline } \\
\text { - Median survival: } 18 \text { mo [248]. }\end{array}$ \\
\hline $\begin{array}{l}\text { cetuximab + } \\
\text { mitoxantrone + } \\
\text { prednisone }\end{array}$ & $\begin{array}{l}\text { EGFR + } \\
\text { topoiso- } \\
\text { merase II + } \\
\text { GR }\end{array}$ & $\begin{array}{l}\mathrm{mCRPC} \\
\text { progressing after } \\
\text { docetaxel }\end{array}$ & Phase II & $\begin{array}{l}\text { Median time to progression (TTP): } 4.9 \text { mo } \\
\text { (cetuximab + mitoxantrone + prednisone) and } 6.6 \text { mo } \\
\text { (mitoxantrone + prednisone); measurable disease } \\
\text { response rate: } 2 \% \text { and } 4 \% \text {; PSA response rate: } 7.7 \% \\
\text { and } 17.6 \% \text {; median survival: } 11.9 \text { and } 15.7 \text { mo, } \\
\text { respectively [249]. }\end{array}$ \\
\hline $\begin{array}{l}\text { cetuximab + } \\
\text { docetaxel }\end{array}$ & $\begin{array}{l}\text { EGFR } \\
\text { +tubulin }\end{array}$ & $\mathrm{mCRPC}$ & Phase II & $\begin{array}{l}7 \text { patients (20\%) and } 11 \text { patients }(31 \%) \text { had } \\
\text { confirmed } \geq 50 \% \text { and } \geq 30 \% \text { PSA declines, } \\
\text { respectively. } \\
\text { Patients overexpressing EGFR and having } \\
\text { persistent PTEN activity had significantly } \\
\text { improved PFS [247]. }\end{array}$ \\
\hline Pertuzumab & $\begin{array}{l}\text { HER2 } \\
\text { dimeriza- } \\
\text { tion }\end{array}$ & $\begin{array}{l}\text { CRPC } \\
\text { progressing after } \\
\text { at least one } \\
\text { taxane-based } \\
\text { regimen }\end{array}$ & Phase II & $\begin{array}{l}\text { - No complete or partial responses (as defined by } \\
\text { Response Evaluation Criteria in Solid Tumors } \\
\text { Group or 50\% decline in PSA). } \\
\text { - } 5 / 30 \text { patients had SD for at least } 23 \text { weeks; } 1 / 5 \\
\text { had SD for } 36 \text { weeks. } \\
\text { - Survival was prolonged with pertuzumab } \\
\text { (16.4 mo), compared with historic controls with } \\
\text { similar baseline prognostic features (10.7 mo) } \\
\text { [250]. }\end{array}$ \\
\hline $\begin{array}{l}\text { Lapatinib } \\
\text { (Tykerb, } \\
\text { GSK572016, } \\
\text { GW2016, } \\
\text { GW-572016) }\end{array}$ & $\begin{array}{l}\text { EGFR and } \\
\text { HER2 }\end{array}$ & $\begin{array}{l}\text { Chemotherapy- } \\
\text { naïve CRPC } \\
\text { patients with } \\
\text { rising PSA on } \\
\text { ADT }\end{array}$ & Phase II & $\begin{array}{l}\text { - } 1 / 21 \text { patients had }>50 \% \text { PSA decline; another } \\
\text { patient had } 47 \% \text { PSA decline ( } 45+\text { mo) } \\
\text { - } \quad \text { Median time to PSA progression: } 29 \text { days [241]. }\end{array}$ \\
\hline \multirow[b]{2}{*}{$\begin{array}{l}\text { Erlotinib } \\
\text { (Tarceva, } \\
\text { CP-358,774, } \\
\text { CP358774, } \\
\text { OSI774, } \\
\text { OSI-774) }\end{array}$} & \multirow[b]{2}{*}{ EGFR } & $\begin{array}{l}\text { Advanced or } \\
\text { metastatic PCa } \\
\text { (including CRPC) }\end{array}$ & Phase II & $\begin{array}{l}\text { - No patients had a PSA decline, } 14 \% \text { had } \\
\text { stabilized PSA. PSA-doubling time increased in } \\
10 \text { patients } \\
\text { - Clinical benefit was achieved in } 40 \% \text { of patients } \\
\text { [244]. }\end{array}$ \\
\hline & & $\begin{array}{l}\text { chemotherapy- } \\
\text { naive } \\
\text { CRPC }\end{array}$ & Phase II & $\begin{array}{l}\text { - } 2 / 22 \text { patients had PR, } 5 \text { had SD; overall clinical } \\
\text { benefit: } 31 \% \text {. } \\
\text { PSA-doubling time: increased from } 3 \text { mo (before } \\
\text { study) to } 6 \text { mo in all responding patients. } \\
\text { - } \quad 2 \text { patients had }>50 \% \text { PSA decline } \\
\text { - Median time to disease progression: } 2 \text { mo; at } \\
\quad 12 \text { mo, } 9 \% \text { of patients were progression-free. } \\
\text { - Median OS: } 16.3 \mathrm{mo} \text {; } 1 \text { - and 2-year survival } \\
\text { rates: } 58 \% \text { and } 27 \% \text {, respectively [243]. }\end{array}$ \\
\hline $\begin{array}{l}\text { Erlotinib + } \\
\text { docetaxel }\end{array}$ & $\begin{array}{l}\text { EGFR + } \\
\text { tubulin }\end{array}$ & $\begin{array}{l}\geq 65 \text { years CRPC } \\
\text { patients } \\
\text { progressing } \\
\text { despite ADT }\end{array}$ & Phase II & $\begin{array}{l}\text { - No OR in } 8 \text { patients with measurable lesions. } \\
1 \text { patient }(5 \%) \text { had bone scan improvement and } \\
\text { PSA decline; } 5 / 22 \text { patients experienced } \geq 50 \% \\
\text { PSA decline [242]. }\end{array}$ \\
\hline $\begin{array}{l}\text { Trastuzumab } \\
\text { (Herceptin) }\end{array}$ & HER2 & CRPC & Phase II & $\begin{array}{l}\text { - } 2 \text { patients had SD (based on PSA decline to } \\
<50 \% \text { of baseline). } \\
\text { - No patient demonstrated a regression of } \\
\text { radiographic bony or soft tissue metastatic } \\
\text { disease [251]. }\end{array}$ \\
\hline
\end{tabular}


Table 1. Cont.

\begin{tabular}{|c|c|c|c|c|}
\hline Agent & Target(s) & Population & Phase & Outcome \\
\hline $\begin{array}{l}\text { Trastuzumab + } \\
\text { docetaxel }\end{array}$ & $\begin{array}{l}\text { HER2 + } \\
\text { tubulin }\end{array}$ & $\begin{array}{l}\text { HER2-positive } \\
\text { CRPC }\end{array}$ & & $\begin{array}{l}\text { - } \quad \text { Mo patient responded to trastuzumab alone. } \\
\text { - } \quad \text { Tas } 7 \text { mo. } \\
\text { - Trial was closed for non-feasibility [253] }\end{array}$ \\
\hline Cediranib & VEGFR & $\begin{array}{l}\text { mCRPC- } \\
\text { progressing } \\
\text { following } \\
\text { docetaxel therapy }\end{array}$ & Phase II & $\begin{array}{l}\text { - } 6 / 39 \text { patients had confirmed PR; } 1 \text { had an } \\
\text { unconfirmed PR. } 43.9 \% \text { of patients were } \\
\text { progression-free at } 6 \text { mo; for all patients, median PFS: } \\
3.7 \text { mo; OS: } 10.1 \text { mo [260] }\end{array}$ \\
\hline Cediranib + DP & VEGFR & mCRPC & Phase II & $\begin{array}{l}\text { - 6-mo PFS rate: } 61 \% \text { in } \mathrm{DP}+\mathrm{C} \text { arm and } 57 \% \text { in DP } \\
\text { arm. There were no significant differences in } 6-\mathrm{mo} \\
\text { OS rate, objective tumor and PSA response rates, and } \\
\text { biomarkers in the two arms [261]. }\end{array}$ \\
\hline $\begin{array}{l}\text { Bevacizumab }+ \\
\text { temsirolimus }\end{array}$ & $\begin{array}{l}\text { VEGF-A \& } \\
\text { MTOR }\end{array}$ & $\begin{array}{l}\text { mCRPC- } \\
\text { previously treated } \\
\text { with } \\
\text { chemotherapy }\end{array}$ & $\begin{array}{l}\text { Phase } \\
\text { I-II }\end{array}$ & $\begin{array}{l}\text { - Median time to progression: } 2.6 \text { mo; median best } \\
\text { PSA change: } 32 \% \text { increase (met the predefined } \\
\text { futility rule leading to early termination of the study) } \\
\text { [262] }\end{array}$ \\
\hline $\begin{array}{l}\text { Bevacizumab + } \\
\text { DP }\end{array}$ & VEGF-A & mCRPC & $\begin{array}{l}\text { Phase } \\
\text { III }\end{array}$ & $\begin{array}{l}\text { - Improved PFS (median, } 9.9 \text { mo for DP+B vs. } \\
7.5 \text { mo for DP) and OR ( } 49.4 \% \text { vs. } 35.5 \% \text {; ) but not OS } \\
\text { (median, } 22.6 \text { mo vs. } 21.5 \text { mo) [255]. }\end{array}$ \\
\hline $\begin{array}{l}\text { bevacizumab }+ \\
\text { docetaxel }+ \\
\text { estramustine }\end{array}$ & $\begin{array}{l}\text { VEGF-A + } \\
\text { tubulin }+ \\
\text { MAPs and } \\
\text { tubulin }\end{array}$ & CRPC & Phase II & $\begin{array}{l}\text { 75\% of patients }(58 / 77) \text { had a } 50 \% \text { PSA decline; } \\
\text { 23/39 patients (59\%) had a PR. } \\
\text { - Median PFS: } 8 \text { mo; median OS: } 24 \text { mo [263]. }\end{array}$ \\
\hline $\begin{array}{l}\text { Dovitinib } \\
\text { (CHIR-258, } \\
\text { TKI258) }\end{array}$ & $\begin{array}{l}\text { VEGFR, } \\
\text { FGFR, } \\
\text { PDGFR }\end{array}$ & $\begin{array}{l}\mathrm{mCRPC}(80 \% \\
\text { were } \\
\text { post-docetaxel })\end{array}$ & Phase II & $\begin{array}{l}\text { - Median PFS: } 3.67 \text { mo; median OS: } 13.70 \text { mo. } \\
\text { Chemotherapy-naïve patients had longer PFS } \\
\text { (17.90 mo) compared with docetaxel-treated } \\
\text { patients ( } 2.07 \text { mo) } \\
\text { Patients with high serum VEGFR2 level over } \\
\text { median level had longer PFS (6.03 mo vs. } \\
1.97 \text { mo) [264]. }\end{array}$ \\
\hline $\begin{array}{l}\text { Pazopanib } \\
\text { (Votrient, } \\
\text { GW786034B) + } \\
\text { bicalutamide }\end{array}$ & $\begin{array}{l}\text { VEGFR + } \\
\text { AR }\end{array}$ & $\begin{array}{l}\text { chemotherapy- } \\
\text { naive } \\
\text { (CRPC). }\end{array}$ & Phase II & $\begin{array}{l}\text { - In arm A (pazopanib), } 1 \text { patient }(11 \%) \text { had a } \\
\text { PSA response (confirmed } \geq 50 \% \text { decline from } \\
\text { baseline), } 3 \text { ( } 33 \% \text { ) had stable PSA, and } 5(56 \%) \\
\text { had PSA progression; In arm B (pazopanib + } \\
\text { bicalutamide), } 2 \text { patients (17\%) had PSA } \\
\text { responses, } 6 \text { (50\%) had stable PSA, and } 4(33 \%) \\
\text { had PSA progression. } \\
\text { Median PFS: } 7.3 \text { mo (similar in both arms); } \\
\text { Long-term SD was seen in } 4 \text { patients remaining } \\
\text { on treatment for } 18 \text { mo and } 26 \text { mo (arm A) and } \\
35 \text { mo and } 52 \text { mo (arm B) [265]. }\end{array}$ \\
\hline $\begin{array}{l}\text { Aflibercept } \\
\text { (Eylea, Zaltrap) } \\
+ \text { Docetaxel + } \\
\text { prednisone }\end{array}$ & $\begin{array}{l}\text { VEGFA/B } \\
\& \text { PGF + } \\
\text { tubulin }+ \\
\text { GR }\end{array}$ & $\begin{array}{l}\text { Chemotherapy- } \\
\text { naïve } \\
\text { mCRPC }\end{array}$ & $\begin{array}{l}\text { Phase } \\
\text { III }\end{array}$ & $\begin{array}{l}\text { - Median OS: } 22 \cdot 1 \text { mo (aflibercept }+ \text { DP) and } \\
21 \cdot 2 \text { mo (DP) no clinical benefit compared to control } \\
\text { group [266]. }\end{array}$ \\
\hline $\begin{array}{l}\text { SU5416 + } \\
\text { dexamethasone }\end{array}$ & VEGFR2 & $\begin{array}{l}\text { Chemotherapy- } \\
\text { naïve } \\
\text { CRPC }\end{array}$ & Phase II & $\begin{array}{l}\text { - No detectable effect on PSA secretion or time to } \\
\text { progression [267]. }\end{array}$ \\
\hline $\begin{array}{l}\text { Thalidomide } \\
\text { (Contergan, } \\
\text { Thalomid, } \\
\text { Talidex) }\end{array}$ & $\begin{array}{l}\text { pro- } \\
\text { angiogenic } \\
\text { factors } \\
\text { (e.g., VEGF, } \\
\text { BFGF, IL-6 }\end{array}$ & $\begin{array}{l}\text { mCRPC (failed } \\
\text { other therapy } \\
\text { forms) }\end{array}$ & Phase II & $\begin{array}{l}\bullet \quad \geq 50 \% \text { PSA decline in } 18 \% \text { of patients } \\
\text { (200 mg/day) but no decline in the high-dose arm } \\
(200 \mathrm{mg} / \text { day to } 1200 \mathrm{mg} / \text { day); PSA decline was } \\
\text { maintained for }>150 \text { days in } 4 \text { patients; } 28 \% \text { of all } \\
\text { patients had }>40 \% \text { PSA decline; } 13 \% \text { had } 40 \% \text { to } 50 \% \\
\text { PSA decline [268]. }\end{array}$ \\
\hline
\end{tabular}


Table 1. Cont.

\begin{tabular}{|c|c|c|c|c|}
\hline Agent & Target(s) & Population & Phase & Outcome \\
\hline & & & & $\begin{array}{l}\text { - } 3 \text { men }(15 \%) \text { had minimum } 50 \% \text { PSA decline } \\
\text { (sustained throughout treatment); } \\
\text { 6/16 (37.5\%) patients (treated for at least } 2 \mathrm{mo}) \text {, } \\
\text { had a median PSA decline of } 48 \% \text {. } \\
\text { Increasing levels of serum bFGF and VEGF } \\
\text { were associated with progressive disease } \\
\text { (5/6 men with PSA decline also demonstrated } \\
\text { decline in bFGF and VEGF levels and } 3 / 4 \text { men } \\
\text { with a rising PSA showed an increase in both } \\
\text { growth factors [269]. }\end{array}$ \\
\hline Itraconazole & $\begin{array}{l}\text { Angioge- } \\
\text { nesis } \\
\text { Hedgehog } \\
\text { signaling }\end{array}$ & $\begin{array}{l}\text { chemotherapy- } \\
\text { naïve } \\
\text { mCRPC }\end{array}$ & Phase II & $\begin{array}{l}\text { - PSA PFS rates at } 24 \text { weeks: } 11.8 \% \text { in } 200 \mathrm{mg} / \text { day } \\
\text { arm and } 48.0 \% \text { in the } 600 \mathrm{mg} / \text { day arm; median PFS: } \\
11.9 \text { weeks and } 35.9 \text { weeks, PSA response rates: } 0 \% \\
\text { and } 14.3 \% \text {, respectively [270]. }\end{array}$ \\
\hline \multirow[t]{2}{*}{ Sorafenib } & \multirow[t]{2}{*}{$\begin{array}{l}\text { RAF } \\
\text { VEGFR2 } \\
\text { PDGFRB }\end{array}$} & \multirow[t]{2}{*}{ mCRPC } & \multirow[t]{2}{*}{ Phase II } & $\begin{array}{l}\text { 13/21 patients with progressive disease } \\
\text { progressed only by PSA criteria without clinical } \\
\text { and radiographic progression. } \\
2 \text { patients met PSA progression criteria at the } \\
\text { time when scans were obtained yet had } \\
\text { dramatic reduction of bone metastatic lesions } \\
\text { (shown by bone scan) [257] }\end{array}$ \\
\hline & & & & $\begin{array}{l}\text { 1/24 patients ( } 21 \text { previously treated with } \\
\text { docetaxel) had a PR; } 10 \text { had SD. } \\
\text { Median PFS: } 3.7 \text { mo; median OS: } 18 \text { mo (median } \\
\text { potential follow-up of } 27.2 \text { mo:); median } \\
\text { survival for the whole trial of } 46 \text { patients: } \\
18.3 \text { mo [258]. }\end{array}$ \\
\hline ISIS 5132 & RAF1 & $\begin{array}{l}\text { chemotherapy- } \\
\text { naïve, } \\
\text { mCRPC }\end{array}$ & Phase II & $\begin{array}{l}\text { - No objective or PSA responses in any treated } \\
\text { patient } \\
\text { - } 1 \text { patient had persistent SD } 6 \text { mo } \\
\text { - } 2 / 16 \text { patients did not have } 25 \% \text { or more rise in } \\
\text { PSA } 120 \text { days post-therapy [256]. }\end{array}$ \\
\hline
\end{tabular}

\section{Conclusions}

Numerous clinical trials have tested inhibitors of PI3K and ERK pathways in CRPC; however, the results of these trials were disappointing. Only the pan-RTK inhibitor cabozantinib, and VEGFR inhibitors aflibercept and bevacizumab, have advanced to stage III trials, yet these trials did not show significant clinical benefits. Perhaps the most telling lesson of these failures, is that the design of clinical trials should be guided by tumor analysis data. Several considerations for future clinical trials can be proposed.

First, patients should be pre-selected based on the evidence of activation of the signaling pathway for a clinical trial that test the inhibitor of this pathway. This approach is supported by the recent results on AKT inhibitors that showed clinical benefits only in patients with active PI3K pathway [211]. Second, the efficacy of the inhibition of the intended target should be monitored. This requirement is more difficult to implement in clinical setting as it requires repeated tumor biopsies or reliable surrogate biomarkers (for example, analysis of hair follicles biopsies for EGFR phosphorylation and GLI levels to control pharmacodynamics of EGFR and Hedgehog inhibitors) [269,270]. Third, the analysis of the biologically relevant targets of signaling pathways should be considered. This is the most difficult condition to satisfy, since despite extensive tissue culture studies, in vivo validation of target proteins responsible for the effects of specific signaling pathways on prostate epithelial cell survival are lacking. Yet, without understanding of what these targets are, what signaling pathways control them, and what alternative signals may compensate for inhibition of the pathway tested in clinical trial, we cannot interpret the results of successful or of failed trials alike. 
Recent data from single cell analysis of prostate epithelial and of prostate stroma cells in mice subjected to androgen ablation, provide convincing support for the indirect regulation of apoptosis in prostate epithelial cells through paracrine factors secreted by stroma cells with active AR signaling [35,45]. This paradigm shift highlights the importance of identifying signaling pathways that are activated by stromal paracrine factors in prostate epithelial cells and the apoptosis regulatory proteins targeted by these pathways. Uncovering how apoptosis is regulated in normal prostates, will guide the experiments that examine whether the same key proteins are regulated in CRPC via AR-independent mechanisms, and whether targeting these mechanisms will provide effective therapies for CRPC.

In prostate cancer cell lines, the proteins of BCL-2 family MCL1, BAK, BAD and BIM can be regulated by signal transduction pathways amenable for pharmacological targeting. Future experiments in transgenic mice with inducible knockout of these proteins, or knock-in of phosphorylation -deficient mutants can assess whether these proteins are responsible for the survival effects of paracrine factors that are regulated by androgens. Confirming the role of these BCL-2 family proteins in maintaining prostate homeostasis in vivo, will justify the clinical testing of these proteins as biomarkers of tumor response to experimental therapies that inhibit signaling pathways that control these proteins. In vivo studies of these critical apoptosis regulators are limited by lack of the reliable technologies that allow to measure protein expression and post-translational modifications at the single cell level. Although the potential of advanced proteomics for analysis of prostate clinical samples is recognized $[269,271]$, the implementation of these technologies lags behind genomic technologies.

In conclusion, extensive experimental data point at the limited number of BCL-2 family proteins as possible targets of signaling pathways that regulate apoptosis in prostate epithelium. The analysis of these proteins in mouse models of prostate cancer, and in patients' PCa samples, will clarify their role in CRPC pathogenesis; hence, forming a foundation for "smart" clinical trials of selective inhibitors that are guided by pathwayspecific biomarkers. These clinical trials will bring about improved personalized therapies that extend the lives of PCa patients; or will show that the research focus should be directed on apoptosis-independent mechanisms of CRPC.

Author Contributions: Writing, visualization, A.A.; writing, review and editing, G.K. All authors have read and agreed to the published version of the manuscript.

Funding: This research was partially funded by Alfaisal University; GK was also supported by the Cancer Center Support grant award P30CA012197 from NIH to Wake Forest Baptist Comprehensive Cancer Center.

Acknowledgments: AA dedicates this work to her parents: “To my parents, my role models, whose endless support, love, and encouragement has always been my source of strength in everything I do." GK dedicates this paper to the memory of Michael J. Weber, a cancer researcher, a mentor and a great "enabler". Authors are grateful to Michael Cox and Daniel Gioeli for insightful comments and to Elizabeth Marnell for proofreading the manuscript.

Conflicts of Interest: The authors declare no conflict of interest. The funders had no role in the design of the study; in the collection, analyses, or interpretation of data; in the writing of the manuscript, or in the decision to publish the results.

\section{References}

1. Rawla, P. Epidemiology of Prostate Cancer. World J. Oncol. 2019, 10, 63-89. [CrossRef]

2. Alghamidi, I.G.; Hussain, I.I.; Alghamdi, M.S.; El-Sheemy, M.A. The Incidence Rate of Prostate Cancer in Saudi Arabia: An Observational Descriptive Epidemiological Analysis of Data from the Saudi Cancer Registry 2001-2008. Hematol. Oncol. Stem Cell Ther. 2014, 7, 18-26. [CrossRef] [PubMed]

3. Perdana, N.R.; Mochtar, C.A.; Umbas, R. The Risk Factors of Prostate Cancer and Its Prevention: A Literature Review. Acta Med. Indones. 2016, 48, 11 .

4. Schrecengost, R.S.; Knudsen, K.E. Molecular Pathogenesis and Progression of Prostate Cancer. Semin. Oncol. 2013, 40, 244-258. [CrossRef] [PubMed] 
5. Singh, S.K.; Apata, T.; Gordetsky, J.B.; Singh, R. Docetaxel Combined with Thymoquinone Induces Apoptosis in Prostate Cancer Cells via Inhibition of the PI3K/AKT Signaling Pathway. Cancers 2019, 11, 1390. [CrossRef] [PubMed]

6. Cattrini, C.; Castro, E.; Lozano, R.; Zanardi, E.; Rubagotti, A.; Boccardo, F.; Olmos, D. Current Treatment Options for Metastatic Hormone-Sensitive Prostate Cancer. Cancers 2019, 11, 1355. [CrossRef]

7. Green, S.M.; Mostaghel, E.A.; Nelson, P.S. Androgen Action and Metabolism in Prostate Cancer. Mol. Cell. Endocrinol. 2012, 360, 3-13. [CrossRef]

8. Daneshmand, S.; Ahmadi, H. Androgen Deprivation Therapy for Prostate Cancer: Long-Term Safety and Patient Outcomes. Patient Relat. Outcome Meas. 2014, 63-70. [CrossRef]

9. Dutt, S.S.; Gao, A.C. Molecular Mechanisms of Castration-Resistant Prostate Cancer Progression. Future Oncol. 2009, 5, 1403-1413. [CrossRef]

10. Zhang, W.; Liao, C.-Y.; Chtatou, H.; Incrocci, L.; van Gent, D.C.; van Weerden, W.M.; Nonnekens, J. Apalutamide Sensitizes Prostate Cancer to Ionizing Radiation via Inhibition of Non-Homologous End-Joining DNA Repair. Cancers 2019, $11,1593$. [CrossRef]

11. Hsieh, A.; Edlind, M. PI3K-AKT-MTOR Signaling in Prostate Cancer Progression and Androgen Deprivation Therapy Resistance. Asian J. Androl. 2014, 16, 378. [CrossRef]

12. Zoubeidi, A.; Gleave, M.E. Co-targeting Driver Pathways in Prostate Cancer: Two Birds with One Stone. EMBO Mol. Med. 2018, 10, e8928. [CrossRef] [PubMed]

13. Carey, A.-M.; Pramanik, R.; Nicholson, L.J.; Dew, T.K.; Martin, F.L.; Muir, G.H.; Morris, J.D.H. Ras-MEK-ERK Signaling Cascade Regulates Androgen Receptor Element-Inducible Gene Transcription and DNA Synthesis in Prostate Cancer Cells. Int. J. Cancer 2007, 121, 520-527. [CrossRef] [PubMed]

14. Crawford, E.D.; Heidenreich, A.; Lawrentschuk, N.; Tombal, B.; Pompeo, A.C.L.; Mendoza-Valdes, A.; Miller, K.; Debruyne, F.M.J.; Klotz, L. Androgen-Targeted Therapy in Men with Prostate Cancer: Evolving Practice and Future Considerations. Prostate Cancer Prostatic Dis. 2019, 22, 24-38. [CrossRef]

15. Tran, C.; Ouk, S.; Clegg, N.J.; Chen, Y.; Watson, P.A.; Arora, V.; Wongvipat, J.; Smith-Jones, P.M.; Yoo, D.; Kwon, A.; et al. Development of a Second-Generation Antiandrogen for Treatment of Advanced Prostate Cancer. Science 2009, 324, 787-790. [CrossRef]

16. Nuhn, P.; De Bono, J.S.; Fizazi, K.; Freedland, S.J.; Grilli, M.; Kantoff, P.W.; Sonpavde, G.; Sternberg, C.N.; Yegnasubramanian, S.; Antonarakis, E.S. Update on Systemic Prostate Cancer Therapies: Management of Metastatic Castration-resistant Prostate Cancer in the Era of Precision Oncology. Eur. Urol. 2019, 75, 88-99. [CrossRef]

17. Bluemn, E.G.; Coleman, I.M.; Lucas, J.M.; Coleman, R.T.; Hernandez-Lopez, S.; Tharakan, R.; Bianchi-Frias, D.; Dumpit, R.F.; Kaipainen, A.; Corella, A.N.; et al. Androgen Receptor Pathway-Independent Prostate Cancer Is Sustained through FGF Signaling. Cancer Cell 2017, 32, 474-489. [CrossRef] [PubMed]

18. Labrecque, M.P.; Coleman, I.M.; Brown, L.G.; True, L.D.; Kollath, L.; Lakely, B.; Nguyen, H.M.; Yang, Y.C.; Gil Da Costa, R.M.; Kaipainen, A.; et al. Molecular profiling stratifies diverse phenotypes of treatment-refractory metastatic castration-resistant prostate cancer. J. Clin. Investig. 2019, 129, 4492-4505. [CrossRef] [PubMed]

19. Lian, F.; Sharma, N.V.; Moran, J.D.; Moreno, C.S. The Biology of Castration-Resistant Prostate Cancer. Curr. Probl. Cancer 2015, 39, 17-28. [CrossRef]

20. Liu, Y. The Context of Prostate Cancer Genomics in Personalized Medicine. Oncol. Lett. 2017, 13, 3347-3353. [CrossRef]

21. Kulik, G. ADRB2-Targeting Therapies for Prostate Cancer. Cancers 2019, 11, 358. [CrossRef]

22. Kerr, J.F.R.; Searle, J. Deletion of Cells by Apoptosis during Castration-Induced Involution of the Rat Prostate. Virchows Arch. B Cell Pathol 1973, 13, 87-102. [CrossRef]

23. Kyprianou, N.; Isaacs, J.T. Activation of Programmed Cell Death in the Rat Ventral Prostate after Castration. Endocrinology 1988, 122, 552-562. [CrossRef]

24. Toivanen, R.; Shen, M.M. Prostate Organogenesis: Tissue Induction, Hormonal Regulation and Cell Type Specification. Development 2017, 144, 1382-1398. [CrossRef] [PubMed]

25. Velcheti, V.; Karnik, S.; Bardot, S.F.; Prakash, O. Pathogenesis of Prostate Cancer: Lessons from Basic Research. Ochsner J. 2008, 8, 213-218.

26. Debes, J.D.; Tindall, D.J. The Role of Androgens and the Androgen Receptor in Prostate Cancer. Cancer Lett. 2002, 187, 1-7. [CrossRef]

27. Fujita, K.; Nonomura, N. Role of Androgen Receptor in Prostate Cancer: A Review. World J. Mens Health 2019, 37, 288. [CrossRef] [PubMed]

28. Regter, S.; Hedayati, M.; Zhang, Y.; Zhou, H.; Dalrymple, S.; Koch, C.J.; Isaacs, J.T.; DeWeese, T.L. Androgen Withdrawal Fails to Induce Detectable Tissue Hypoxia in the Rat Prostate: Undetectable Tissue Hypoxia in the Rat Prostate. Prostate 2014, 74, 805-810. [CrossRef] [PubMed]

29. Huggins, C.; Clark, P.J. Quantitative Studies of Prostatic Secretion II. The Effect of Castration and of Estrogen Injection on the Normal and on the Hyperplastic Prostate Glands of Dogs. J. Exp. Med. 1940, 747-762. [CrossRef]

30. Helminen, H.J.; Ericsson, J.L.E. Ultrastructural Studies on Prostatic Involution in the Rat Changes in the Secretory Pathways. J. Ultrastruct. Res. 1972, 40, 152-166. [CrossRef] 
31. Sandford, N.L.; Searle, J.W.; Kerr, J.F.R. Successive Waves of Apoptosis in the Rat Prostate after Repeated Withdrawal of Testosterone Stimulation. Pathology 1984, 16, 406-410. [CrossRef]

32. English, H.F.; Santen, R.J.; Lsaacs, J.T. Response of Glandular versus Basal Rat Ventral Prostatic Epithelial Cells to Androgen Withdrawal and Replacement. Prostate 1987, 11, 229-242. [CrossRef]

33. Bruckheimer, E.M.; Cho, S.; Brisbay, S.; Johnson, D.J.; Greenberg, N.; McDonnell, T.J. The Impact of Bcl-2 Expression and Bax Defciency on Prostate Homeostasis. Oncogene 2000, 19, 2404-2412. [CrossRef]

34. Kurita, T.; Wang, Y.Z.; Donjacour, A.A.; Zhao, C.; Lydon, J.P.; O’Malley, B.W.; Isaacs, J.T.; Dahiya, R.; Cunha, G.R. Paracrine Regulation of Apoptosis by Steroid Hormones in the Male and Female Reproductive System. Cell Death Differ. 2001, 8, 192-200. [CrossRef]

35. Karthaus, W.R.; Hofree, M.; Choi, D.; Linton, E.L.; Turkekul, M.; Bejnood, A.; Carver, B.; Gopalan, A.; Abida, W.; Laudone, V.; et al. Regenerative Potential of Prostate Luminal Cells Revealed by Single-Cell Analysis. Science 2020, 368, 497-505. [CrossRef] [PubMed]

36. Niu, Y.; Wang, J.; Shang, Z.; Huang, S.-P.; Shyr, C.-R.; Yeh, S.; Chang, C. Increased CK5/CK8-Positive Intermediate Cells with Stromal Smooth Muscle Cell Atrophy in the Mice Lacking Prostate Epithelial Androgen Receptor. PLoS ONE 2011, 6, e20202. [CrossRef]

37. Wu, C.-T.; Altuwaijri, S.; Ricke, W.A.; Huang, S.-P.; Yeh, S.; Zhang, C.; Niu, Y.; Tsai, M.-Y.; Chang, C. Increased Prostate Cell Proliferation and Loss of Cell Differentiation in Mice Lacking Prostate Epithelial Androgen Receptor. Proc. Natl. Acad. Sci. USA 2007, 104, 12679-12684. [CrossRef] [PubMed]

38. Niu, Y.; Altuwaijri, S.; Lai, K.-P.; Wu, C.-T.; Ricke, W.A.; Messing, E.M.; Yao, J.; Yeh, S.; Chang, C. Androgen Receptor Is a Tumor Suppressor and Proliferator in Prostate Cancer. Proc. Natl. Acad. Sci. USA 2008, 105, 12182-12187. [CrossRef] [PubMed]

39. Stanbrough, M.; Leav, I.; Kwan, P.W.L.; Bubley, G.J.; Balk, S.P. Prostatic Intraepithelial Neoplasia in Mice Expressing an Androgen Receptor Transgene in Prostate Epithelium. Proc. Natl. Acad. Sci. USA 2001, 10823-10828. [CrossRef]

40. Yu, S.; Zhang, C.; Lin, C.-C.; Niu, Y.; Lai, K.-P.; Chang, H.; Yeh, S.-D.; Chang, C.; Yeh, S. Altered Prostate Epithelial Development and IGF-1 Signal in Mice Lacking the Androgen Receptor in Stromal Smooth Muscle Cells. Prostate 2011, 71, 517-524. [CrossRef] [PubMed]

41. Welsh, M.; Moffat, L.; McNeilly, A.; Brownstein, D.; Saunders, P.T.K.; Sharpe, R.M.; Smith, L.B. Smooth Muscle Cell-Specific Knockout of Androgen Receptor: A New Model for Prostatic Disease. Endocrinology 2011, 152, 3541-3551. [CrossRef]

42. Yu, S.; Yeh, C.-R.; Niu, Y.; Chang, H.-C.; Tsai, Y.-C.; Moses, H.L.; Shyr, C.-R.; Chang, C.; Yeh, S. Altered Prostate Epithelial Development in Mice Lacking the Androgen Receptor in Stromal Fibroblasts: Altered Prostate Epithelial Development in Mice. Prostate 2012, 72, 437-449. [CrossRef] [PubMed]

43. Lai, K.-P.; Yamashita, S.; Vitkus, S.; Shyr, C.-R.; Yeh, S.; Chang, C. Suppressed Prostate Epithelial Development with Impaired Branching Morphogenesis in Mice Lacking Stromal Fibromuscular Androgen Receptor. Mol. Endocrinol. 2012, $26,52-66$. [CrossRef] [PubMed]

44. Wen, S.; Chang, H.-C.; Tian, J.; Shang, Z.; Niu, Y.; Chang, C. Stromal Androgen Receptor Roles in the Development of Normal Prostate, Benign Prostate Hyperplasia, and Prostate Cancer. Am. J. Pathol. 2015, 185, 293-301. [CrossRef]

45. Xie, Q.; Liu, Y.; Cai, T.; Horton, C.; Stefanson, J.; Wang, Z.A. Dissecting Cell-Type-Specific Roles of Androgen Receptor in Prostate Homeostasis and Regeneration through Lineage Tracing. Nat. Commun. 2017, 8, 14284. [CrossRef]

46. Godoy, A.; Montecinos, V.P.; Gray, D.R.; Sotomayor, P.; Yau, J.M.; Vethanayagam, R.R.; Singh, S.; Mohler, J.L.; Smith, G.J. Androgen Deprivation Induces Rapid Involution and Recovery of Human Prostate Vasculature. Am. J. Physiol. Endocrinol. Metab. 2011, 300, E263-E275. [CrossRef]

47. Lekås, E.; Johansson, M.; Widmark, A.; Bergh, A.; Damber, J.-E. Decrement of Blood Flow Precedes the Involution of the Ventral Prostate in the Rat after Castration. Urol. Res. 1997, 25, 309-314. [CrossRef] [PubMed]

48. Shabsigh, A.; Ghafar, M.A.; Anastasiadis, A.G.; Buttyan, R. Biomarker Analysis Demonstrates a Hypoxic Environment in the Castrated Rat Ventral Prostate Gland. J. Cell. Biochem. 2001, 81, 437-444. [CrossRef]

49. Verbrugge, I.; Johnstone, R.W.; Smyth, M.J. SnapShot: Extrinsic Apoptosis Pathways. Cell 2010, 143, 1192-1192.e2. [CrossRef]

50. Mongiat, M.; Ligresti, G.; Marastoni, S.; Lorenzon, E.; Doliana, R.; Colombatti, A. Regulation of the Extrinsic Apoptotic Pathway by the Extracellular Matrix Glycoprotein EMILIN2. Mol. Cell. Biol. 2007, 27, 7176-7187. [CrossRef] [PubMed]

51. French, L.E.; Hahne, M.; Viard, I.; Radlgruber, G.; Zanone, R.; Becker, K.; Müller, C.; Tschopp, J. Fas and Fas Ligand in Embryos and Adult Mice: Ligand Expression in Several Immune-Privileged Tissues and Coexpression in Adult Tissues Characterized by Apoptotic Cell Turnover. J. Cell Biol. 1996, 133, 335-343. [CrossRef] [PubMed]

52. Xerri, L.; Devilard, E.; Hassoun, J.; Mawas, C.; Birg, F. Fas Ligand Is Not Only Expressed in Immune Privileged Human Organs but Is Also Coexpressed with Fas in Various Epithelial Tissues. Mol. Pathol. 1997, 50, 87-91. [CrossRef]

53. Liu, Q.-Y.; Rubin, M.A.; Omene, C.; Lederman, S.; Stein, C.A. Fas Ligand Is Constitutively Secreted by Prostate Cancer Cells in Vitro. Clin. Cancer Res. 1998, 4, 1803-1811. [PubMed]

54. Hyer, M.L.; Voelkel-Johnson, C.; Rubinchik, S.; Dong, J.; Norris, J.S. Intracellular Fas Ligand Expression Causes Fas-Mediated Apoptosis in Human Prostate Cancer Cells Resistant to Monoclonal Antibody-Induced Apoptosis. Mol. Ther. 2000, 2, 348-358. [CrossRef] [PubMed]

55. Suzuki, A.; Matsuzawa, A.; Iguchi, T. Down Regulation of Bcl-2 Is the First Step on Fas-Mediated Apoptosis of Male Reproductive Tract. Oncogene 1996, 13, 31-37. 
56. De la Taille, A.; Chen, M.W.; Shabsigh, A.; Bagiella, E.; Kiss, A.; Buttyan, R. Fas Antigen/CD-95 Upregulation and Activation during Castration-Induced Regression of the Rat Ventral Prostate Gland. Prostate 1999, 40, 89-96. [CrossRef]

57. Gao, S.; Lee, P.; Wang, H.; Gerald, W.; Adler, M.; Zhang, L.; Wang, Y.-F.; Wang, Z. The Androgen Receptor Directly Targets the Cellular Fas/FasL-Associated Death Domain Protein-Like Inhibitory Protein Gene to Promote the Androgen-Independent Growth of Prostate Cancer Cells. Mol. Endocrinology 2005, 19, 1792-1802. [CrossRef] [PubMed]

58. Raclaw, K.A.; Heemers, H.V.; Kidd, E.M.; Dehm, S.M.; Tindall, D.J. Induction of FLIP Expression by Androgens Protects Prostate Cancer Cells from TRAIL-Mediated Apoptosis. Prostate 2008, 68, 1696-1706. [CrossRef] [PubMed]

59. Cornforth, A.N.; Davis, J.S.; Khanifar, E.; Nastiuk, K.L.; Krolewski, J.J. FOXO3a Mediates the Androgen-Dependent Regulation of FLIP and Contributes to TRAIL-Induced Apoptosis of LNCaP Cells. Oncogene 2008, 27, 4422-4433. [CrossRef] [PubMed]

60. Wang, D.; Lu, J.; Tindall, D.J. Androgens Regulate TRAIL-Induced Cell Death in Prostate Cancer Cells via Multiple Mechanisms. Cancer Lett. 2013, 335, 136-144. [CrossRef] [PubMed]

61. Perlman, H.; Zhang, X.; Chen, M.W.; Walsh, K.; Buttyan, R. An Elevated Bax/Bcl-2 Ratio Corresponds with the Onset of Prostate Epithelial Cell Apoptosis. Cell Death Differ. 1999, 6, 48-54. [CrossRef]

62. Wei, M.C.; Zong, W.-X.; Cheng, E.H.-Y.; Lindsten, T.; Panoutsakopoulou, V.; Ross, A.J.; Roth, K.A.; MacGregor, G.R.; Thompson, C.B.; Korsmeyer, S.J. Proapoptotic BAX and BAK: A Requisite Gateway to Mitochondrial Dysfunction and Death. Science 2001, 292, 727-730. [CrossRef]

63. Zhang, X.; Chen, M.W.; Ng, A.; Ng, P.Y.; Lee, C.; Rubin, M.; Olsson, C.A.; Buttyan, R. Abnormal Prostate Development in C3(1)-Bcl-2 Transgenic Mice. Prostate 1997, 32, 16-26. [CrossRef]

64. Cui, J.; Placzek, W. Post-Transcriptional Regulation of Anti-Apoptotic BCL2 Family Members. Int. J. Mol. Sci. 2018, 19, 308. [CrossRef]

65. Wang, C.; Youle, R.J. The Role of Mitochondria in Apoptosis. Ann. Rev. Genet. 2009, 43, 95-118. [CrossRef] [PubMed]

66. Green, D.R. Apoptotic Pathways: Paper Wraps Stone Blunts Scissors. Cell 2000, 102, 1-4. [CrossRef]

67. Adams, J.M.; Cory, S. The BCL-2 Arbiters of Apoptosis and Their Growing Role as Cancer Targets. Cell Death Differ. 2018, 25, 27-36. [CrossRef] [PubMed]

68. Wolf, P. Tumor-Specific Induction of the Intrinsic Apoptotic Pathway-A New Therapeutic Option for Advanced Prostate Cancer? Front. Oncol. 2019, 9, 590. [CrossRef] [PubMed]

69. Karnak, D.; Xu, L. Chemosensitization of Prostate Cancer by Modulating Bcl-2 Family Proteins. Curr. Drug Targets 2010, 11, 699-707. [CrossRef] [PubMed]

70. Chaudhary, K.S.; Abel, P.D.; Lalani, E.-N. Role of the BcI-2 Gene Family in Prostate Cancer Progression and Its Implications for Therapeutic Intervention. Environ. Health Perspect. 1999, 107, 49-57. [CrossRef]

71. Haldar, S.; Negrini, M.; Monne, M.; Sabbioni, S.; Croce, C.M. Down-Regulation of Bcl-2 by P53 in Breast Cancer Cells. Cancer Res. 1994, 54, 2095-2097.

72. Loeb, D.M. WT1 Influences Apoptosis Through Transcriptional Regulation of Bcl-2 Family Members. Cell Cycle 2006, 5, 1249-1253. [CrossRef] [PubMed]

73. Catz, S.D.; Johnson, J.L. Transcriptional Regulation of Bcl-2 by Nuclear Factor KB and Its Significance in Prostate Cancer. Oncogene 2001, 20, 7342-7351. [CrossRef] [PubMed]

74. Kim, S.J.; Kelly, W.K.; Fu, A.; Haines, K.; Hoffman, A.; Zheng, T.; Zhu, Y. Genome-Wide Methylation Analysis Identifies Involvement of TNF- $\alpha$ Mediated Cancer Pathways in Prostate Cancer. Cancer Lett. 2011, 302, 47-53. [CrossRef] [PubMed]

75. Song, T.; Wang, P.; Yu, X.; Wang, A.; Chai, G.; Fan, Y.; Zhang, Z. Systems Analysis of Phosphorylation-Regulated Bcl-2 Interactions Establishes a Model to Reconcile the Controversy over the Significance of Bcl-2 Phosphorylation: Enhanced Anti-Apoptotic Ability of Phosphorylated Bcl-2. Br. J. Pharmacol. 2019, 176, 491-504. [CrossRef]

76. Hockenbery, D.M.; Zutter, M.; Hickey, W.; Nahm, M.; Korsmeyer, S.J. BCL2 Protein Is Topographically Restricted in Tissues Characterized by Apoptotic Cell Death. Proc. Natl. Acad. Sci. USA 1991, 88, 6961-6965. [CrossRef]

77. Catz, S.D.; Johnson, J.L. BCL-2 in Prostate Cancer: A Minireview. Apoptosis 2003, 8, 29-37. [CrossRef]

78. McDonnell, T.J.; Troncoso, P.; Brisbay, S.M.; Logothetis, C.; Chung, L.W.K.; Hsieh, J.-T.; Tu, S.-M.; Campbell, M.L. Expression of the Protooncogene Bcl-2 in the Prostate and Its Association with Emergence of Androgen-Independent Prostate Cancer. Cancer Res. 1992, 52, 6940-6944.

79. Love, H.D.; Booton, S.E.; Boone, B.E.; Breyer, J.P.; Koyama, T.; Revelo, M.P.; Shappell, S.B.; Smith, J.R.; Hayward, S.W. Androgen Regulated Genes in Human Prostate Xenografts in Mice: Relation to BPH and Prostate Cancer. PLoS ONE 2009, 4 , e8384. [CrossRef]

80. Westin, P.; Stattin, P.; Damber, J.-E. Castration Therapy Rapidly Induces Apoptosis in a Minority and Decreases Cell Proliferation in a Majority of Human Prostatic Tumors. Am. J. Pathol. 1995, 146, 1368-1375.

81. Symmans, F.; Gil, S.; Chopin, D.; Olsson, C.A.; Korsmeyer, S.; Buttyan, R. Detection of the Apoptosis-Suppressing Oncoprotein Bcl-2 in Hormone-Refractory Human Prostate Cancers. Am. J. Pathol. 1993, 143, 390-400.

82. Li, Q.; Deng, Q.; Chao, H.-P.; Liu, X.; Lu, Y.; Lin, K.; Liu, B.; Tang, G.W.; Zhang, D.; Tracz, A.; et al. Linking Prostate Cancer Cell AR Heterogeneity to Distinct Castration and Enzalutamide Responses. Nat. Commun. 2018, 9, 3600. [CrossRef]

83. Bonkhoff, H.; Fixemer, T.; Remberger, K. Relation between Bcl-2, Cell Proliferation, and the Androgen Receptor Status in Prostate Tissue and Precursors of Prostate Cancer. Prostate 1998, 34, 251-258. [CrossRef] 
84. Raffo, A.J.; Perlman, H.; Chen, M.-W.; Day, M.L.; Streitman, J.S.; Buttyan, R. Overexpression of Bcl-2 Protects Prostate Cancer Cells from Apoptosis in Vitro and Confers Resistance to Androgen Depletion in Vivo. Cancer Res. 1995, 55, 4438-4445. [PubMed]

85. Placzek, W.J.; Wei, J.; Kitada, S.; Zhai, D.; Reed, J.C.; Pellecchia, M. A Survey of the Anti-Apoptotic Bcl-2 Subfamily Expression in Cancer Types Provides a Platform to Predict the Efficacy of Bcl-2 Antagonists in Cancer Therapy. Cell Death Dis. 2010, 1, e40. [CrossRef] [PubMed]

86. Karni, R.; Jove, R.; Levitzki, A. Inhibition of Pp60c-Src Reduces Bcl-XL Expression and Reverses the Transformed Phenotype of Cells Overexpressing EGF and HER-2 Receptors. Oncogene 1999, 18, 4654-4662. [CrossRef] [PubMed]

87. Grad, J.M.; Zeng, X.-R.; Boise, L.H. Regulation of Bcl-XL: A Little Bit of This and a Little Bit of STAT. Curr. Opin. Oncol. 2000, 12, 543-549. [CrossRef]

88. Boise, H.; GonzBlez-Garcia, M.; Postema, E.; Ding, L.; Turka, L.A.; NuAez, G. Bcl-x, a Bcl-2-Related Gene That Functions as a Dominant Regulator of Apoptotic Cell Death. Cell 1993, 74, 597-608. [CrossRef]

89. Poruchynsky, M.S.; Wang, E.E.; Rudin, C.M.; Blagosklonny, M.V.; Fojo, T. Bcl-XL Is Phosphorylated in Malignant Cells Following Microtubule Disruption. Cancer Res. 1998, 58, 3331-3338.

90. Clem, R.J.; Cheng, E.H.-Y.; Karp, C.L.; Kirsch, D.G.; Ueno, K.; Takahashi, A.; Kastan, M.B.; Griffin, D.E.; Earnshaw, W.C.; Veliuona, M.A.; et al. Modulation of Cell Death by Bcl-XL through Caspase Interaction. Proc. Natl. Acad. Sci. USA 1998, 95, 554-559. [CrossRef]

91. Beaumatin, F.; El Dhaybi, M.; Bobo, C.; Verdier, M.; Priault, M. Bcl-XL Deamidation and Cancer: Charting the Fame Trajectories of Legitimate Child and Hidden Siblings. Biochim. Biophys. Acta Mol. Cell Res. 2017, 1864, 1734-1745. [CrossRef]

92. Krajewska, M.; Krajewski, S. Immunohistochemical Analysis of Bcl-2, Bax, Bcl-X, and Mcl-1 Expression in Prostate Cancers. Am. J. Pathol. 1996, 148, 1567-1576.

93. Castilla, C.; Congregado, B.; Chinchón, D.; Torrubia, F.J.; Japón, M.A.; Sáez, C. Bcl-XL Is Overexpressed in Hormone-Resistant Prostate Cancer and Promotes Survival of LNCaP Cells via Interaction with Proapoptotic Bak. Endocrinology 2006, 147, $4960-4967$. [CrossRef]

94. Marcelli, M.; Marani, M.; Li, X.; Sturgis, L.; Haidacher, S.J.; Trial, J.; Mannucci, R.; Nicoletti, I.; Denner, L. Heterogeneous Apoptotic Responses of Prostate Cancer Cell Lines Identify an Association between Sensitivity to Staurosporine-Induced Apoptosis, Expression of Bcl-2 Family Members, and Caspase Activation. Prostate 2000, 42, 260-273. [CrossRef]

95. Yancey, D.; Nelson, K.C.; Baiz, D.; Hassan, S.; Flores, A.; Pullikuth, A.; Karpova, Y.; Axanova, L.; Moore, V.; Sui, G.; et al. BAD Dephosphorylation and Decreased Expression of MCL-1 Induce Rapid Apoptosis in Prostate Cancer Cells. PLoS ONE 2013, 8, e74561. [CrossRef] [PubMed]

96. Sun, A.; Tang, J.; Hong, Y.; Song, J.; Terranova, P.F.; Thrasher, J.B.; Svojanovsky, S.; Wang, H.; Li, B. Androgen Receptor-Dependent Regulation of Bcl-XL Expression: Implication in Prostate Cancer Progression. Prostate 2008, 68, 453-461. [CrossRef] [PubMed]

97. Li, F.; Pascal, L.E.; Zhou, J.; Zhou, Y.; Wang, K.; Parwani, A.V.; Dhir, R.; Guo, P.; He, D.; Nelson, J.B.; et al. BCL-2 and BCL-XL Expression Are down-Regulated in Benign Prostate Hyperplasia Nodules and Not Affected by Finasteride and/or Celecoxib. Am. J. Clin. Exp. Urol. 2018, 6, 1-10. [PubMed]

98. Lamb, L.E.; Zarif, J.C.; Miranti, C.K. The Androgen Receptor Induces Integrin A6ß1 to Promote Prostate Tumor Cell Survival via NF-KB and Bcl-XL Independently of PI3K Signaling. Cancer Res. 2011, 71, 2739-2749. [CrossRef]

99. Shore, G.; Warr, M. Unique Biology of Mcl-1: Therapeutic Opportunities in Cancer. Curr. Mol. Med. 2008, 8, 138-147. [CrossRef]

100. Senichkin, V.V.; Streletskaia, A.Y.; Gorbunova, A.S.; Zhivotovsky, B.; Kopeina, G.S. Saga of Mcl-1: Regulation from Transcription to Degradation. Cell Death Differ. 2020, 27, 405-419. [CrossRef]

101. Chipuk, J.E.; Moldoveanu, T.; Llambi, F.; Parsons, M.J.; Green, D.R. The BCL-2 Family Reunion. Mol. Cell 2010, 37, 299-310. [CrossRef] [PubMed]

102. Opferman, J.T. Attacking Cancer's Achilles Heel: Antagonism of Anti-Apoptotic BCL-2 Family Members. FEBS J. 2016, 283, 2661-2675. [CrossRef] [PubMed]

103. Zhang, S.; Zhau, H.E.; Osunkoya, A.O.; Iqbal, S.; Yang, X.; Fan, S.; Chen, Z.; Wang, R.; Marshall, F.F.; Chung, L.W.; et al. Vascular Endothelial Growth Factor Regulates Myeloid Cell Leukemia-1 Expression through Neuropilin-1-Dependent Activation of c-MET Signaling in Human Prostate Cancer Cells. Mol. Cancer 2010, 9, 9. [CrossRef]

104. Santer, F.R.; Erb, H.H.H.; Oh, S.J.; Handle, F.; Feiersinger, G.E.; Luef, B.; Bu, H.; Schäfer, G.; Ploner, C.; Egger, M.; et al. Mechanistic Rationale for MCL1 Inhibition during Androgen Deprivation Therapy. Oncotarget 2015, 6, 6105-6122. [CrossRef] [PubMed]

105. Cavarretta, I.T.; Neuwirt, H.; Zaki, M.H.; Steiner, H.; Hobisch, A.; Nemeth, J.A.; Culig, Z. Mcl-1 is Regulated by IL-6 and Mediates the Survival Activity of the Cytokine in a Model of Late Stage Prostate Carcinoma. In Hormonal Carcinogenesis V; Li, J.J., Li, S.A., Mohla, S., Rochefort, H., Maudelonde, T., Eds.; Advances in Experimental Medicine and, Biology; Springer: New York, NY, USA, 2008; Volume 617, pp. 547-555. ISBN 978-0-387-69078-0.

106. Hassan, S.; Pullikuth, A.; Nelson, K.C.; Flores, A.; Karpova, Y.; Baiz, D.; Zhu, S.; Sui, G.; Huang, Y.; Choi, Y.A.; et al. B2Adrenoreceptor Signaling Increases Therapy Resistance in Prostate Cancer by Upregulating MCL1. Mol. Cancer Res. 2020, 18, 1839-1848. [CrossRef] [PubMed]

107. Iqbal, S.; Zhang, S.; Driss, A.; Liu, Z.-R.; Kim, H.-R.C.; Wang, Y.; Ritenour, C.; Zhau, H.E.; Kucuk, O.; Chung, L.W.K.; et al. PDGF Upregulates Mcl-1 Through Activation of $\beta$-Catenin and HIF- $1 \alpha$-Dependent Signaling in Human Prostate Cancer Cells. PLoS ONE 2012, 7, e30764. [CrossRef] [PubMed] 
108. Arai, S.; Jonas, O.; Whitman, M.A.; Corey, E.; Balk, S.P.; Chen, S. Tyrosine Kinase Inhibitors Increase MCL1 Degradation and in Combination with BCLXL/BCL2 Inhibitors Drive Prostate Cancer Apoptosis. Clin. Cancer Res. 2018, 24, 5458-5470. [CrossRef]

109. Arai, S.; Varkaris, A.; Nouri, M.; Chen, S.; Xie, L.; Balk, S.P. MARCH5 Mediates NOXA-Dependent MCL1 Degradation Driven by Kinase Inhibitors and Integrated Stress Response Activation. eLife 2020, 9, e54954. [CrossRef]

110. Dash, R.; Richards, J.E.; Su, Z.; Bhutia, S.K.; Azab, B.; Rahmani, M.; Dasmahapatra, G.; Yacoub, A.; Dent, P.; Dmitriev, I.P.; et al Mechanism by Which Mcl-1 Regulates Cancer-Specific Apoptosis Triggered by Mda-7/IL-24, an IL-10-Related Cytokine. Cancer Res. 2010, 70, 5034-5045. [CrossRef]

111. Pompeia, C.; Hodge, D.R.; Plass, C.; Wu, Y.-Z.; Marquez, V.E.; Kelley, J.A.; Farrar, W.L. Microarray Analysis of Epigenetic Silencing of Gene Expression in the KAS-6/1 Multiple Myeloma Cell Line. Cancer Res. 2004, 64, 3465-3473. [CrossRef]

112. Pisani, C.; Ramella, M.; Boldorini, R.; Loi, G.; Billia, M.; Boccafoschi, F.; Volpe, A.; Krengli, M. Apoptotic and Predictive Factors by Bax, Caspases 3/9, Bcl-2, P53 and Ki-67 in Prostate Cancer after 12 Gy Single-Dose. Sci. Rep. 2020, 10, 7050. [CrossRef]

113. Khor, L.Y.; Moughan, J.; Al-Saleem, T.; Hammond, E.H.; Venkatesan, V.; Rosenthal, S.A.; Ritter, M.A.; Sandler, H.M.; Hanks, G.E.; Shipley, W.U.; et al. Bcl-2 and Bax Expression Predict Prostate Cancer Outcome in Men Treated with Androgen Deprivation and Radiotherapy on Radiation Therapy Oncology Group Protocol 92-02. Clin. Cancer Res. 2007, 13, 3585-3590. [CrossRef]

114. Krajewski, S.; Krajewska, M.; Reed, J.C. Immunohistochemical Analysis of in Vivo Patterns of Bak Expression, a Proapoptotic Member of the Bcl-2 Protein Family. Cancer Res. 1996, 56, 2849-2855. [PubMed]

115. Liu, Q.Y.; Stein, C.A. Taxol and Estramustine-Induced Modulation of Human Prostate Cancer Cell Apoptosis via Alteration in Bcl-XL and Bak Expression. Clin. Cancer Res. 1997, 3, 2039-2046. [PubMed]

116. Don, M.-J.; Chang, Y.-H.; Chen, K.-K.; Ho, L.-K.; Chau, Y.-P. Induction of CDK Inhibitors (P21WAF1 and P27Kip1) and Bak in the Beta-Lapachone-Induced Apoptosis of Human Prostate Cancer Cells. Mol. Pharmacol. 2001, 59, 784-794. [CrossRef]

117. Xiao, D.; Lew, K.L.; Kim, Y.-A.; Zeng, Y.; Hahm, E.-R.; Dhir, R.; Singh, S.V. Diallyl Trisulfide Suppresses Growth of PC-3 Human Prostate Cancer Xenograft In Vivo in Association with Bax and Bak Induction. Clin. Cancer Res. 2006, 12, 6836-6843. [CrossRef]

118. Fox, J.L.; Storey, A. BMX Negatively Regulates BAK Function, Thereby Increasing Apoptotic Resistance to Chemotherapeutic Drugs. Cancer Res. 2015, 75, 1345-1355. [CrossRef]

119. Chen, S.; Cai, C.; Sowalsky, A.G.; Ye, H.; Ma, F.; Yuan, X.; Simon, N.I.; Gray, N.S.; Balk, S.P. BMX-Mediated Regulation of Multiple Tyrosine Kinases Contributes to Castration Resistance in Prostate Cancer. Cancer Res. 2018, 78, 5203-5215. [CrossRef]

120. Lomonosova, E.; Chinnadurai, G. BH3-Only Proteins in Apoptosis and beyond: An Overview. Oncogene 2008, 27, S2-S19. [CrossRef] [PubMed]

121. Bui, N.L.; Pandey, V.; Zhu, T.; Ma, L.; Basappa; Lobie, P.E. Bad Phosphorylation as a Target of Inhibition in Oncology. Cancer Lett. 2018, 415, 177-186. [CrossRef]

122. Danial, N.N. BAD: Undertaker by Night, Candyman by Day. Oncogene 2008, 27, S53-S70. [CrossRef]

123. Oltersdorf, T.; Elmore, S.W.; Shoemaker, A.R.; Armstrong, R.C.; Augeri, D.J.; Belli, B.A.; Bruncko, M.; Deckwerth, T.L.; Dinges, J.; Hajduk, P.J.; et al. An Inhibitor of Bcl-2 Family Proteins Induces Regression of Solid Tumours. Nature 2005, 435, 677-681. [CrossRef] [PubMed]

124. Royuela, M.; Arenas, M.I.; Bethencourt, F.R.; Sanchez-Chapado, M.; Fraile, B.; Paniagua, R. Immunoexpressions of P21, Rb, Mcl-1 and Bad Gene Products in Normal, Hyperplastic and Carcinomatous Human Prostates. Eur. Cytokine Netw. 2001, 12, 654-663. [PubMed]

125. Teo, K.; Gemmell, L.; Mukherjee, R.; Traynor, P.; Edwards, J. Bad Expression Influences Time to Androgen Escape in Prostate Cancer. BJU Int. 2007, 100, 691-696. [CrossRef]

126. Chao, O.S.P.; Clément, M.-V. Epidermal Growth Factor and Serum Activate Distinct Pathways to Inhibit the BH3 Only Protein BAD in Prostate Carcinoma LNCaP Cells. Oncogene 2006, 25, 4458-4469. [CrossRef]

127. Meshki, J.; Caino, M.C.; von Burstin, V.A.; Griner, E.; Kazanietz, M.G. Regulation of Prostate Cancer Cell Survival by Protein Kinase C $€$ Involves Bad Phosphorylation and Modulation of the TNF $\alpha / J N K$ Pathway. J. Biol. Chem. 2010, 285, 26033-26040. [CrossRef] [PubMed]

128. Fukumori, T.; Oka, N.; Takenaka, Y.; Nangia-Makker, P.; Elsamman, E.; Kasai, T.; Shono, M.; Kanayama, H.; Ellerhorst, J.; Lotan, R.; et al. Galectin-3 Regulates Mitochondrial Stability and Antiapoptotic Function in Response to Anticancer Drug in Prostate Cancer. Cancer Res. 2006, 66, 3114-3119. [CrossRef] [PubMed]

129. Misra, U.K.; Deedwania, R.; Pizzo, S.V. Activation and Cross-Talk between Akt, NF-KB, and Unfolded Protein Response Signaling in 1-LN Prostate Cancer Cells Consequent to Ligation of Cell Surface-Associated GRP78. J. Biol. Chem. 2006, 281, 13694-13707. [CrossRef] [PubMed]

130. Sastry, K.S.R.; Smith, A.J.; Karpova, Y.; Datta, S.R.; Kulik, G. Diverse Antiapoptotic Signaling Pathways Activated by Vasoactive Intestinal Polypeptide, Epidermal Growth Factor, and Phosphatidylinositol 3-Kinase in Prostate Cancer Cells Converge on BAD. J. Biol. Chem. 2006, 281, 20891-20901. [CrossRef]

131. Sastry, K.S.R.; Karpova, Y.; Kulik, G. Epidermal Growth Factor Protects Prostate Cancer Cells from Apoptosis by Inducing BAD Phosphorylation via Redundant Signaling Pathways. J. Biol. Chem. 2006, 281, 27367-27377. [CrossRef]

132. Sastry, K.S.R.; Karpova, Y.; Prokopovich, S.; Smith, A.J.; Essau, B.; Gersappe, A.; Carson, J.P.; Weber, M.J.; Register, T.C.; Chen, Y.Q.; et al. Epinephrine Protects Cancer Cells from Apoptosis via Activation of CAMP-Dependent Protein Kinase and BAD Phosphorylation. J. Biol. Chem. 2007, 282, 14094-14100. [CrossRef] [PubMed] 
133. Berquin, I.M.; Min, Y.; Wu, R.; Wu, J.; Perry, D.; Cline, J.M.; Thomas, M.J.; Thornburg, T.; Kulik, G.; Smith, A.; et al. Modulation of Prostate Cancer Genetic Risk by Omega-3 and Omega-6 Fatty Acids. J. Clin. Invest. 2007, 117, 1866-1875. [CrossRef]

134. Ammar, H.; Closset, J.L. Clusterin Activates Survival through the Phosphatidylinositol 3-Kinase/Akt Pathway. J. Biol. Chem. 2008, 283, 12851-12861. [CrossRef] [PubMed]

135. Mumenthaler, S.M.; Ng, P.Y.B.; Hodge, A.; Bearss, D.; Berk, G.; Kanekal, S.; Redkar, S.; Taverna, P.; Agus, D.B.; Jain, A. Pharmacologic Inhibition of Pim Kinases Alters Prostate Cancer Cell Growth and Resensitizes Chemoresistant Cells to Taxanes. Mol. Cancer Ther. 2009, 8, 2882-2893. [CrossRef]

136. Zhang, M.; Siedow, M.; Saia, G.; Chakravarti, A. Inhibition of P21-Activated Kinase 6 (PAK6) Increases Radiosensitivity of Prostate Cancer Cells: PAK6 and Prostate Cancer. Prostate 2010, 70, 807-816. [CrossRef] [PubMed]

137. Zoubeidi, A.; Zardan, A.; Wiedmann, R.M.; Locke, J.; Beraldi, E.; Fazli, L.; Gleave, M.E. Hsp27 Promotes Insulin-Like Growth Factor-I Survival Signaling in Prostate Cancer via P90Rsk-Dependent Phosphorylation and Inactivation of BAD. Cancer Res. 2010, 70, 2307-2317. [CrossRef] [PubMed]

138. Morgan, T.; Koreckij, T.; Corey, E. Targeted Therapy for Advanced Prostate Cancer: Inhibition of the PI3K/Akt/MTOR Pathway. Curr. Cancer Drug Targets 2009, 9, 237-249. [CrossRef]

139. Tan, Y.; Demeter, M.R.; Ruan, H.; Comb, M.J. BAD Ser-155 Phosphorylation Regulates BAD/Bcl-XL Interaction and Cell Survival. J. Biol. Chem. 2000, 275, 25865-25869. [CrossRef]

140. Dramsi, S.; Scheid, M.P.; Maiti, A.; Hojabrpour, P.; Chen, X.; Schubert, K.; Goodlett, D.R.; Aebersold, R.; Duronio, V. Identification of a Novel Phosphorylation Site, Ser-170, as a Regulator of Bad Pro-apoptotic Activity. J. Biol. Chem. 2002, 277, 6399-6405. [CrossRef]

141. Sionov, R.V.; Vlahopoulos, S.A.; Granot, Z. Regulation of Bim in Health and Disease. Oncotarget 2015, 6, 23058-23134. [CrossRef] [PubMed]

142. Liu, J.-W.; Chandra, D.; Tang, S.-H.; Chopra, D.; Tang, D.G. Identification and Characterization of Bimgamma, a Novel Proapoptotic BH3-Only Splice Variant of Bim. Cancer Res. 2002, 62, 2976-2981. [PubMed]

143. Tan, T.-T.; Degenhardt, K.; Nelson, D.A.; Beaudoin, B.; Nieves-Neira, W.; Bouillet, P.; Villunger, A.; Adams, J.M.; White, E. Key Roles of BIM-Driven Apoptosis in Epithelial Tumors and Rational Chemotherapy. Cancer Cell 2005, 7, 227-238. [CrossRef]

144. Aira, L.E.; Villa, E.; Colosetti, P.; Gamas, P.; Signetti, L.; Obba, S.; Proics, E.; Gautier, F.; Bailly-Maitre, B.; Jacquel, A.; et al. The Oncogenic Tyrosine Kinase Lyn Impairs the Pro-Apoptotic Function of Bim. Oncogene 2018, 37, 2122-2136. [CrossRef]

145. Gogada, R.; Yadav, N.; Liu, J.; Tang, S.; Zhang, D.; Schneider, A.; Seshadri, A.; Sun, L.; Aldaz, C.M.; Tang, D.G.; et al. Bim, a Proapoptotic Protein, Up-Regulated via Transcription Factor E2F1-Dependent Mechanism, Functions as a Prosurvival Molecule in Cancer. J. Biol. Chem. 2013, 288, 368-381. [CrossRef]

146. Yang, M.-C.; Lin, R.-W.; Huang, S.-B.; Huang, S.-Y.; Chen, W.-J.; Wang, S.; Hong, Y.-R.; Wang, C. Bim Directly Antagonizes Bcl-Xl in Doxorubicin-Induced Prostate Cancer Cell Apoptosis Independently of P53. Cell Cycle 2016, 15, 394-402. [CrossRef] [PubMed]

147. Wu, F.; Lin, Y.; Cui, P.; Li, H.; Zhang, L.; Sun, Z.; Huang, S.; Li, S.; Huang, S.; Zhao, Q.; et al. Cdc20/P55 Mediates the Resistance to Docetaxel in Castration-Resistant Prostate Cancer in a Bim-Dependent Manner. Cancer Chemother. Pharmacol. 2018, 81, 999-1006. [CrossRef]

148. Kinkade, C.W.; Castillo-Martin, M.; Puzio-Kuter, A.; Yan, J.; Foster, T.H.; Gao, H.; Sun, Y.; Ouyang, X.; Gerald, W.L.; Cordon-Cardo, C.; et al. Targeting AKT/MTOR and ERK MAPK Signaling Inhibits Hormone-Refractory Prostate Cancer in a Preclinical Mouse Model. J. Clin. Invest. 2008, 3051-3064. [CrossRef] [PubMed]

149. Yu, J.; Zhang, L. PUMA, a Potent Killer with or without P53. Oncogene 2008, 27, S71-S83. [CrossRef] [PubMed]

150. Yamashita, M.; Kuwahara, M.; Suzuki, A.; Hirahara, K.; Shinnaksu, R.; Hosokawa, H.; Hasegawa, A.; Motohashi, S.; Iwama, A.; Nakayama, T. Bmi1 Regulates Memory CD4 T Cell Survival via Repression of the Noxa Gene. J. Exp. Med. 2008, 205, 1109-1120. [CrossRef]

151. Albert, M.-C.; Brinkmann, K.; Kashkar, H. Noxa and Cancer Therapy: Tuning up the Mitochondrial Death Machinery in Response to Chemotherapy. Mol. Cell. Oncol. 2014, 1, e29906. [CrossRef]

152. Diallo, J.-S.; Aldejmah, A.; Mouhim, A.F.; Péant, B.; Fahmy, M.A.; Koumakpayi, I.H.; Sircar, K.; Bégin, L.R.; Mes-Masson, A.-M.; Saad, F. NOXA and PUMA Expression Add to Clinical Markers in Predicting Biochemical Recurrence of Prostate Cancer Patients in a Survival Tree Model. Clin. Cancer Res. 2007, 13, 7044-7052. [CrossRef]

153. Dey, P.; Ström, A.; Gustafsson, J.-Å. Estrogen Receptor $\beta$ Upregulates FOXO3a and Causes Induction of Apoptosis through PUMA in Prostate Cancer. Oncogene 2014, 33, 4213-4225. [CrossRef] [PubMed]

154. Meng, Y.; Tang, W.; Dai, Y.; Wu, X.; Liu, M.; Ji, Q.; Ji, M.; Pienta, K.; Lawrence, T.; Xu, L. Natural BH3 Mimetic (-)-Gossypol Chemosensitizes Human Prostate Cancer via Bcl-XL Inhibition Accompanied by Increase of Puma and Noxa. Mol. Cancer Ther. 2008, 7, 2192-2202. [CrossRef]

155. Pang, C.-Y.; Chiu, S.-C.; Harn, H.-J.; Zhai, W.-J.; Lin, S.-Z.; Yang, H.-H. Proteomic-Based Identification of Multiple Pathways Underlying n-Butylidenephthalide-Induced Apoptosis in LNCaP Human Prostate Cancer Cells. Food Chem. Toxicol. 2013, 59, 281-288. [CrossRef]

156. Nikrad, M.; Johnson, T.; Puthalalath, H.; Coultas, L.; Adams, J.; Kraft, A.S. The Proteasome Inhibitor Bortezomib Sensitizes Cells to Killing by Death Receptor Ligand TRAIL via BH3-Only Proteins Bik and Bim. Mol. Cancer Ther. 2005, 4, 443-449. [CrossRef] 
157. Hockings, C.; Anwari, K.; Ninnis, R.L.; Brouwer, J.; O’Hely, M.; Evangelista, M.; Hinds, M.G.; Czabotar, P.E.; Lee, E.F.; Fairlie, W.D.; et al. Bid Chimeras Indicate That Most BH3-Only Proteins Can Directly Activate Bak and Bax, and Show No Preference for Bak versus Bax. Cell Death Dis. 2015, 6, e1735. [CrossRef] [PubMed]

158. Luo, X.; O'Neill, K.L.; Huang, K. The Third Model of Bax/Bak Activation: A Bcl-2 Family Feud Finally Resolved? F1000Res 2020, 9, 935. [CrossRef] [PubMed]

159. Sax, J.K.; Fei, P.; Murphy, M.E.; Bernhard, E.; Korsmeyer, S.J.; El-Deiry, W.S. BID Regulation by P53 Contributes to Chemosensitivity. Nat. Cell Biol. 2002, 4, 842-849. [CrossRef] [PubMed]

160. Erler, J.T.; Cawthorne, C.J.; Williams, K.J.; Koritzinsky, M.; Wouters, B.G.; Wilson, C.; Miller, C.; Demonacos, C.; Stratford, I.J.; Dive, C. Hypoxia-Mediated Down-Regulation of Bid and Bax in Tumors Occurs via Hypoxia-Inducible Factor 1-Dependent and -Independent Mechanisms and Contributes to Drug Resistance. Mol. Cell. Biol. 2004, 24, 2875-2889. [CrossRef] [PubMed]

161. Krajewska, M.; Zapata, J.M.; Meinhold-Heerlein, I.; Hedayat, H.; Monks, A.; Bettendorf, H.; Shabaik, A.; Bubendorf, L.; Kallioniemi, O.-P.; Kim, H.; et al. Expression of Bcl-2 Family Member Bid in Normal and Malignant Tissues. Neoplasia 2002, 4, 129-140. [CrossRef]

162. Nesterov, A.; Lu, X.; Johnson, M.; Miller, G.J.; Ivashchenko, Y.; Kraft, A.S. Elevated Akt Activity Protects the Prostate Cancer Cell Line LNCaP from TRAIL-Induced Apoptosis. J. Biol. Chem. 2001, 276, 10767-10774. [CrossRef] [PubMed]

163. Nimmanapalli, R.; Perkins, C.L.; Orlando, M.; O’Bryan, E.; Nguyen, D.; Bhalla, K.N. Pretreatment with Paclitaxel Enhances Apo-2 Ligand/Tumor Necrosis Factor- Related Apoptosis-Inducing Ligand-Induced Apoptosis of Prostate Cancer Cells by Inducing Death Receptors 4 and 5 Protein Levels. Cancer Res. 2001, 61, 759-763.

164. Kulik, G.; Carson, J.P.; Vomastek, T.; Overman, K.; Gooch, B.D.; Srinivasula, S.; Alnemri, E.; Nunez, G.; Weber, M.J. Tumor Necrosis Factor Alpha Induces BID Cleavage and Bypasses Antiapoptotic Signals in Prostate Cancer LNCaP Cells. Cancer Res. 2001, 61, 2713-2719. [PubMed]

165. Rokhlin, O.W.; Guseva, N.; Tagiyev, A.; Knudson, C.M.; Cohen, M.B. Bcl-2 Oncoprotein Protects the Human Prostatic Carcinoma Cell Line PC3 from TRAIL-Mediated Apoptosis. Oncogene 2001, 20, 2836-2843. [CrossRef]

166. Chen, X.; Thakkar, H.; Tyan, F.; Gim, S.; Robinson, H.; Lee, C.; Pandey, S.K.; Nwokorie, C.; Onwudiwe, N.; Srivastava, R.K. Constitutively Active Akt Is an Important Regulator of TRAIL Sensitivity in Prostate Cancer. Oncogene 2001, 20, 6073-6083. [CrossRef] [PubMed]

167. Sharma, N.; Pellegrini, K.; Ouellet, V.; Giuste, F.; Ramalingam, S.; Watanabe, K.; Adam-Granger, E.; Fossouo, L.; You, S.; Freeman, M.; et al. Identification of the Transcription Factor Relationships Associated with Androgen Deprivation Therapy Response and Metastatic Progression in Prostate Cancer. Cancers 2018, 10, 379. [CrossRef]

168. Wang, G.; Wang, Y.; Feng, W.; Wang, X.; Yang, J.Y.; Zhao, Y.; Wang, Y.; Liu, Y. Transcription Factor and MicroRNA Regulation in Androgen-Dependent and -Independent Prostate Cancer Cells. BMC Genom. 2008, 9, S22. [CrossRef]

169. Volante, M.; Tota, D.; Giorcelli, J.; Bollito, E.; Napoli, F.; Vatrano, S.; Buttigliero, C.; Molinaro, L.; Gontero, P.; Porpiglia, F.; et al. Androgen Deprivation Modulates Gene Expression Profile along Prostate Cancer Progression. Hum. Pathol. 2016, 56, 81-88. [CrossRef] [PubMed]

170. Manning, B.D.; Toker, A. AKT/PKB Signaling: Navigating the Network. Cell 2017, 169, 381-405. [CrossRef]

171. Henderson, V.; Smith, B.; Burton, L.J.; Randle, D.; Morris, M.; Odero-Marah, V.A. Snail Promotes Cell Migration through PI3K/AKT-Dependent Rac1 Activation as Well as PI3K/AKT-Independent Pathways during Prostate Cancer Progression. Cell Adhes. Migr. 2015, 9, 255-264. [CrossRef]

172. Porter, G.W.; Khuri, F.R.; Fu, H. Dynamic 14-3-3/Client Protein Interactions Integrate Survival and Apoptotic Pathways. Semin. Cancer Biol. 2006, 16, 193-202. [CrossRef] [PubMed]

173. Peso, L.D. Interleukin-3-Induced Phosphorylation of BAD Through the Protein Kinase Akt. Science 1997, 278, 687-689. [CrossRef]

174. Qi, X.-J.; Wildey, G.M.; Howe, P.H. Evidence That Ser87 of BimEL Is Phosphorylated by Akt and Regulates BimEL Apoptotic Function. J. Biol. Chem. 2006, 281, 813-823. [CrossRef] [PubMed]

175. Aslan, J.E.; You, H.; Williamson, D.M.; Endig, J.; Youker, R.T.; Thomas, L.; Shu, H.; Du, Y.; Milewski, R.L.; Brush, M.H.; et al. Akt and 14-3-3 Control a PACS-2 Homeostatic Switch That Integrates Membrane Traffic with TRAIL-Induced Apoptosis. Mol. Cell 2009, 34, 497-509. [CrossRef] [PubMed]

176. You, H.; Pellegrini, M.; Tsuchihara, K.; Yamamoto, K.; Hacker, G.; Erlacher, M.; Villunger, A.; Mak, T.W. FOXO3a-Dependent Regulation of Puma in Response to Cytokine/Growth Factor Withdrawal. J. Exp. Med. 2006, 203, 1657-1663. [CrossRef] [PubMed]

177. Brunet, A.; Bonni, A.; Zigmond, M.J.; Lin, M.Z.; Juo, P.; Hu, L.S.; Anderson, M.J.; Arden, K.C.; Blenis, J.; Greenberg, M.E. Akt Promotes Cell Survival by Phosphorylating and Inhibiting a Forkhead Transcription Factor. Cell 1999, 96, 857-868. [CrossRef]

178. Rokudai, S.; Fujita, N.; Kitahara, O.; Nakamura, Y.; Tsuruo, T. Involvement of FKHR-Dependent TRADD Expression in Chemotherapeutic Drug-Induced Apoptosis. Mol. Cell. Biol. 2002, 22, 8695-8708. [CrossRef]

179. Dijkers, P.F.; Medema, R.H.; Lammers, J.-W.J.; Koenderman, L.; Coffer, P.J. Expression of the Pro-Apoptotic Bcl-2 Family Member Bim Is Regulated by the Forkhead Transcription Factor FKHR-L1. Curr. Biol. 2000, 10, 1201-1204. [CrossRef]

180. Wang, J.-M.; Chao, J.-R.; Chen, W.; Kuo, M.-L.; Yen, J.J.-Y.; Yang-Yen, H.-F. The Antiapoptotic Gene Mcl-1 Is Up-Regulated by the Phosphatidylinositol 3-Kinase/Akt Signaling Pathway through a Transcription Factor Complex Containing CREB. Mol. Cell. Biol. 1999, 19, 6195-6206. [CrossRef] [PubMed]

181. Kuo, M.-L.; Chuang, S.-E.; Lin, M.-T.; Yang, S.-Y. The Involvement of PI 3-K/Akt-Dependent up-Regulation of Mcl-1 in the Prevention of Apoptosis of Hep3B Cells by Interleukin-6. Oncogene 2001, 20, 677-685. [CrossRef] [PubMed] 
182. Anderson, G.R.; Wardell, S.E.; Cakir, M.; Crawford, L.; Leeds, J.C.; Nussbaum, D.P.; Shankar, P.S.; Soderquist, R.S.; Stein, E.M.; Tingley, J.P.; et al. PIK3CA Mutations Enable Targeting of a Breast Tumor Dependency through MTOR-Mediated MCL-1 Translation. Sci. Transl. Med. 2016, 8, 369ra175. [CrossRef] [PubMed]

183. Maurer, U.; Charvet, C.; Wagman, A.S.; Dejardin, E.; Green, D.R. Glycogen Synthase Kinase-3 Regulates Mitochondrial Outer Membrane Permeabilization and Apoptosis by Destabilization of MCL-1. Mol. Cell 2006, 21, 749-760. [CrossRef]

184. Wozney, J.L.; Antonarakis, E.S. Growth Factor and Signaling Pathways and Their Relevance to Prostate Cancer Therapeutics. Cancer Metastasis Rev. 2014, 33, 581-594. [CrossRef]

185. Shen, M.M.; Abate-Shen, C. Pten Inactivation and the Emergence of Androgen-Independent Prostate Cancer. Cancer Res. 2007, 67, 6535-6538. [CrossRef] [PubMed]

186. Rodríguez-Berriguete, G.; Fraile, B.; Martínez-Onsurbe, P.; Olmedilla, G.; Paniagua, R.; Royuela, M. MAP Kinases and Prostate Cancer. J. Signal Transduct. 2012, 2012, 1-9. [CrossRef] [PubMed]

187. Mebratu, Y.; Tesfaigzi, Y. How ERK1/2 Activation Controls Cell Proliferation and Cell Death: Is Subcellular Localization the Answer? Cell Cycle 2009, 8, 1168-1175. [CrossRef] [PubMed]

188. McCubrey, J.A.; Steelman, L.S.; Chappell, W.H.; Abrams, S.L.; Wong, E.W.T.; Chang, F.; Lehmann, B.; Terrian, D.M.; Milella, M.; Tafuri, A.; et al. Roles of the Raf/MEK/ERK Pathway in Cell Growth, Malignant Transformation and Drug Resistance. Biochim. Biophys. Acta 2007, 1773, 1263-1284. [CrossRef] [PubMed]

189. Sulzmaier, F.J.; Ramos, J.W. RSK Isoforms in Cancer Cell Invasion and Metastasis. Cancer Res. 2013, 73, 6099-6105. [CrossRef] [PubMed]

190. Mulholland, D.J.; Kobayashi, N.; Ruscetti, M.; Zhi, A.; Tran, L.M.; Huang, J.; Gleave, M.; Wu, H. Ptenloss and RAS/MAPK Activation Cooperate to Promote EMT and Metastasis Initiated from Prostate Cancer Stem/Progenitor Cells. Cancer Res. 2012, 72, 1878-1889. [CrossRef]

191. Nickols, N.G.; Nazarian, R.; Zhao, S.G.; Tan, V.; Uzunangelov, V.; Xia, Z.; Baertsch, R.; Neeman, E.; Gao, A.C.; Thomas, G.V.; et al. MEK-ERK Signaling Is a Therapeutic Target in Metastatic Castration Resistant Prostate Cancer. Prostate Cancer Prostatic Dis. 2019, 22, 531-538. [CrossRef] [PubMed]

192. Gioeli, D.; Mandell, J.W.; Petroni, G.R.; Frierson, H.F.; Weber, M.J. Activation of Mitogen-Activated Protein Kinase Associated with Prostate Cancer Progression. Cancer Res. 1999, 59, 279-284. [PubMed]

193. Mukherjee, R.; McGuinness, D.H.; McCall, P.; Underwood, M.A.; Seywright, M.; Orange, C.; Edwards, J. Upregulation of MAPK Pathway Is Associated with Survival in Castrate-Resistant Prostate Cancer. Br. J. Cancer 2011, 104, 1920-1928. [CrossRef] [PubMed]

194. Gao, H.; Ouyang, X.; Banach-Petrosky, W.A.; Gerald, W.L.; Shen, M.M.; Abate-Shen, C. Combinatorial Activities of Akt and B-Raf/Erk Signaling in a Mouse Model of Androgen-Independent Prostate Cancer. Proc. Natl. Acad. Sci. USA 2006, 103, 14477-14482. [CrossRef]

195. Labanca, E.; Vazquez, E.S.; Corn, P.G.; Roberts, J.M.; Wang, F.; Logothetis, C.J.; Navone, N.M. Fibroblast Growth Factors Signaling in Bone Metastasis. Endocr. Relat. Cancer 2020, 27, R255-R265. [CrossRef]

196. Sastry, K.S.; Chouchane, A.I.; Wang, E.; Kulik, G.; Marincola, F.M.; Chouchane, L. Cytoprotective Effect of Neuropeptides on Cancer Stem Cells: Vasoactive Intestinal Peptide-Induced Antiapoptotic Signaling. Cell Death Dis. 2017, 8, e2844. [CrossRef] [PubMed]

197. Zhao, Y.; Li, W. Beta-Adrenergic Signaling on Neuroendocrine Differentiation, Angiogenesis, and Metastasis in Prostate Cancer Progression. Asian J. Androl. 2019, 21, 253. [CrossRef] [PubMed]

198. Braadland, P.R.; Ramberg, H.; Grytli, H.H.; Taskén, K.A. $\beta$-Adrenergic Receptor Signaling in Prostate Cancer. Front. Oncol. 2015, 4. [CrossRef] [PubMed]

199. Langer, I. Mechanisms Involved in VPAC Receptors Activation and Regulation: Lessons from Pharmacological and Mutagenesis Studies. Front. Endocrinol. 2012, 3, 129. [CrossRef] [PubMed]

200. Collado, B.; Carmena, M.; Sánchez-Chapado, M.; Ruíz-Villaespesa, A.; Bajo, A.; Fernández-Martínez, A.; Varga, J.; Schally, A.; Prieto, J. Expression of Vasoactive Intestinal Peptide and Functional VIP Receptors in Human Prostate Cancer: Antagonistic Action of a Growth-Hormone-Releasing Hormone Analog. Int. J. Oncol. 2005. [CrossRef] [PubMed]

201. Xie, Y.; Wolff, D.W.; Lin, M.-F.; Tu, Y. Vasoactive Intestinal Peptide Transactivates the Androgen Receptor through a Protein Kinase A-Dependent Extracellular Signal-Regulated Kinase Pathway in Prostate Cancer LNCaP Cells. Mol. Pharmacol. 2007, 72, 73-85. [CrossRef]

202. Lemeshow, S.; Sørensen, H.T.; Phillips, G.; Yang, E.V.; Antonsen, S.; Riis, A.H.; Lesinski, G.B.; Jackson, R.; Glaser, R. $\beta$-Blockers and Survival among Danish Patients with Malignant Melanoma: A Population-Based Cohort Study. Cancer Epidemiol. Biomark. Prev. 2011, 20, 2273-2279. [CrossRef] [PubMed]

203. Giorgi, V.D.; Grazzini, M.; Gandini, S.; Benemei, S.; Lotti, T.; Marchionni, N.; Geppetti, P. Treatment with $\beta$-Blockers and Reduced Disease Progression in Patients with Thick Melanoma. Arch. Intern. Med. 2011, 171, 3. [CrossRef]

204. Baek, M.-H.; Kim, D.-Y.; Kim, S.O.; Kim, Y.-J.; Park, Y.-H. Impact of Beta Blockers on Survival Outcomes in Ovarian Cancer: A Nationwide Population-Based Cohort Study. J. Gynecol. Oncol. 2018, 29, e82. [CrossRef] [PubMed]

205. Campbell, J.P.; Karolak, M.R.; Ma, Y.; Perrien, D.S.; Masood-Campbell, S.K.; Penner, N.L.; Munoz, S.A.; Zijlstra, A.; Yang, X.; Sterling, J.A.; et al. Stimulation of Host Bone Marrow Stromal Cells by Sympathetic Nerves Promotes Breast Cancer Bone Metastasis in Mice. PLoS Biol. 2012, 10, e1001363. [CrossRef] [PubMed] 
206. Palm, D.; Lang, K.; Niggemann, B.; Drell, T.L.; Masur, K.; Zaenker, K.S.; Entschladen, F. The Norepinephrine-Driven Metastasis Development of PC-3 Human Prostate Cancer Cells in BALB/c Nude Mice Is Inhibited by $\beta$-Blockers. Int. J. Cancer 2006, 118, 2744-2749. [CrossRef] [PubMed]

207. Grytli, H.H.; Fagerland, M.W.; Fosså, S.D.; Taskén, K.A. Association Between Use of $\beta$-Blockers and Prostate Cancer-Specific Survival: A Cohort Study of 3561 Prostate Cancer Patients with High-Risk or Metastatic Disease. Eur. Urol. 2014, 65, 635-641. [CrossRef] [PubMed]

208. Grytli, H.H.; Fagerland, M.W.; Fosså, S.D.; Taskén, K.A.; Håheim, L.L. Use of $\beta$-Blockers Is Associated with Prostate CancerSpecific Survival in Prostate Cancer Patients on Androgen Deprivation Therapy: $\beta$-Blocker Use and Prostate Cancer Survival. Prostate 2013, 73, 250-260. [CrossRef] [PubMed]

209. Brohée, L.; Peulen, O.; Nusgens, B.; Castronovo, V.; Thiry, M.; Colige, A.C.; Deroanne, C.F. Propranolol Sensitizes Prostate Cancer Cells to Glucose Metabolism Inhibition and Prevents Cancer Progression. Sci. Rep. 2018, 8, 7050. [CrossRef] [PubMed]

210. Asdaq, S.M.B.; Inamdar, M.N. Pharmacodynamic and Pharmacokinetic Interactions of Propranolol with Garlic (Allium Sativum) in Rats. Evid. Based Complement. Altern. Med. 2011, 2011, 1-11. [CrossRef]

211. De Bono, J.S.; De Giorgi, U.; Rodrigues, D.N.; Massard, C.; Bracarda, S.; Font, A.; Arranz Arija, J.A.; Shih, K.C.; Radavoi, G.D.; Xu, N.; et al. Randomized Phase II Study Evaluating Akt Blockade with Ipatasertib, in Combination with Abiraterone, in Patients with Metastatic Prostate Cancer with and without PTEN Loss. Clin. Cancer Res. 2019, 25, 928-936. [CrossRef] [PubMed]

212. Armstrong, A.J.; Halabi, S.; Healy, P.; Alumkal, J.J.; Winters, C.; Kephart, J.; Bitting, R.L.; Hobbs, C.; Soleau, C.F.; Beer, T.M.; et al. Phase II Trial of the PI3 Kinase Inhibitor Buparlisib (BKM-120) with or without Enzalutamide in Men with Metastatic Castration Resistant Prostate Cancer. Eur. J. Cancer 2017, 81, 228-236. [CrossRef]

213. Hotte, S.J.; Chi, K.N.; Joshua, A.M.; Tu, D.; Macfarlane, R.J.; Gregg, R.W.; Ruether, J.D.; Basappa, N.S.; Finch, D.; Salim, M.; et al. A Phase II Study of PX-866 in Patients with Recurrent or Metastatic Castration-Resistant Prostate Cancer: Canadian Cancer Trials Group Study IND205. Clin. Genitourin. Cancer 2019, 17, 201-208.e1. [CrossRef] [PubMed]

214. Graham, L.; Banda, K.; Torres, A.; Carver, B.S.; Chen, Y.; Pisano, K.; Shelkey, G.; Curley, T.; Scher, H.I.; Lotan, T.L.; et al. A Phase II Study of the Dual MTOR Inhibitor MLN0128 in Patients with Metastatic Castration Resistant Prostate Cancer. Invest. New Drugs 2018, 36, 458-467. [CrossRef]

215. Armstrong, A.J.; Shen, T.; Halabi, S.; Kemeny, G.; Bitting, R.L.; Kartcheske, P.; Embree, E.; Morris, K.; Winters, C.; Jaffe, T.; et al. A Phase II Trial of Temsirolimus in Men with Castration-Resistant Metastatic Prostate Cancer. Clin. Genitourin. Cancer 2013, 11, 397-406. [CrossRef]

216. Emmenegger, U.; Booth, C.M.; Berry, S.; Sridhar, S.S.; Winquist, E.; Bandali, N.; Chow, A.; Lee, C.; Xu, P.; Man, S.; et al. Temsirolimus Maintenance Therapy After Docetaxel Induction in Castration-Resistant Prostate Cancer. Oncologist 2015, 20, 1351-1352. [CrossRef]

217. Kruczek, K.; Ratterman, M.; Tolzien, K.; Sulo, S.; Lestingi, T.M.; Nabhan, C. A Phase II Study Evaluating the Toxicity and Efficacy of Single-Agent Temsirolimus in Chemotherapy-Naïve Castration-Resistant Prostate Cancer. Br. J. Cancer 2013, 109, 1711-1716. [CrossRef] [PubMed]

218. Meulenbeld, H.J.; de Bono, J.S.; Tagawa, S.T.; Whang, Y.E.; Li, X.; Heath, K.H.; Zandvliet, A.S.; Ebbinghaus, S.W.; Hudes, G.R.; de Wit, R. Tolerability, Safety and Pharmacokinetics of Ridaforolimus in Combination with Bicalutamide in Patients with Asymptomatic, Metastatic Castration-Resistant Prostate Cancer (CRPC). Cancer Chemother. Pharmacol. 2013, 72, 909-916. [CrossRef] [PubMed]

219. Vaishampayan, U.; Shevrin, D.; Stein, M.; Heilbrun, L.; Land, S.; Stark, K.; Li, J.; Dickow, B.; Heath, E.; Smith, D.; et al. Phase II Trial of Carboplatin, Everolimus, and Prednisone in Metastatic Castration-Resistant Prostate Cancer Pretreated with Docetaxel Chemotherapy: A Prostate Cancer Clinical Trial Consortium Study. Urology 2015, 86, 1206-1211. [CrossRef]

220. Templeton, A.J.; Dutoit, V.; Cathomas, R.; Rothermundt, C.; Bärtschi, D.; Dröge, C.; Gautschi, O.; Borner, M.; Fechter, E.; Stenner, F.; et al. Phase 2 Trial of Single-Agent Everolimus in Chemotherapy-Naive Patients with Castration-Resistant Prostate Cancer (SAKK 08/08). Eur. Urol. 2013, 64, 150-158. [CrossRef]

221. Nakabayashi, M.; Werner, L.; Courtney, K.D.; Buckle, G.; Oh, W.K.; Bubley, G.J.; Hayes, J.H.; Weckstein, D.; Elfiky, A.; Sims, D.M.; et al. Phase II Trial of RAD001 and Bicalutamide for Castration-Resistant Prostate Cancer: Phase II Trial of RAD001 and Bicalutamide. BJU Int. 2012, 110, 1729-1735. [CrossRef] [PubMed]

222. Chow, H.; Ghosh, P.M.; de Vere White, R.; Evans, C.P.; Dall’Era, M.A.; Yap, S.A.; Li, Y.; Beckett, L.A.; Lara, P.N.; Pan, C.-X. A Phase 2 Clinical Trial of Everolimus plus Bicalutamide for Castration-Resistant Prostate Cancer: Everolimus and Bicalutamide for CRPC. Cancer 2016, 122, 1897-1904. [CrossRef]

223. Rathkopf, D.E.; Larson, S.M.; Anand, A.; Morris, M.J.; Slovin, S.F.; Shaffer, D.R.; Heller, G.; Carver, B.; Rosen, N.; Scher, H.I. Everolimus Combined with Gefitinib in Patients with Metastatic Castration-Resistant Prostate Cancer: Phase 1/2 Results and Signaling Pathway Implications: Everolimus and Gefitinib in CRPC. Cancer 2015, 121, 3853-3861. [CrossRef]

224. Amato, R.J.; Wilding, G.; Bubley, G.; Loewy, J.; Haluska, F.; Gross, M.E. Safety and Preliminary Efficacy Analysis of the MTOR Inhibitor Ridaforolimus in Patients with Taxane-Treated, Castration-Resistant Prostate Cancer. Clin. Genitourin. Cancer 2012, 10, 232-238. [CrossRef]

225. Rathi, N.; Maughan, B.L.; Agarwal, N.; Swami, U. Mini-Review: Cabozantinib in the Treatment of Advanced Renal Cell Carcinoma and Hepatocellular Carcinoma. Cancer Manag. Res. 2020, 12, 3741-3749. [CrossRef] 
226. Smith, D.C.; Smith, M.R.; Sweeney, C.; Elfiky, A.A.; Logothetis, C.; Corn, P.G.; Vogelzang, N.J.; Small, E.J.; Harzstark, A.L.; Gordon, M.S.; et al. Cabozantinib in Patients with Advanced Prostate Cancer: Results of a Phase II Randomized Discontinuation Trial. J. Clin. Oncol. 2013, 31, 412-419. [CrossRef]

227. Schöffski, P.; Gordon, M.; Smith, D.C.; Kurzrock, R.; Daud, A.; Vogelzang, N.J.; Lee, Y.; Scheffold, C.; Shapiro, G.I. Phase II Randomised Discontinuation Trial of Cabozantinib in Patients with Advanced Solid Tumours. Eur. J. Cancer 2017, 86, 296-304. [CrossRef] [PubMed]

228. Smith, M.R.; Sweeney, C.J.; Corn, P.G.; Rathkopf, D.E.; Smith, D.C.; Hussain, M.; George, D.J.; Higano, C.S.; Harzstark, A.L.; Sartor, A.O.; et al. Cabozantinib in Chemotherapy-Pretreated Metastatic Castration-Resistant Prostate Cancer: Results of a Phase II Nonrandomized Expansion Study. J. Clin. Oncol. 2014, 32, 3391-3399. [CrossRef]

229. Smith, M.; De Bono, J.; Sternberg, C.; Le Moulec, S.; Oudard, S.; De Giorgi, U.; Krainer, M.; Bergman, A.; Hoelzer, W.; De Wit, R.; et al. Phase III Study of Cabozantinib in Previously Treated Metastatic Castration-Resistant Prostate Cancer: COMET-1. J. Clin. Oncol. 2016, 34, 3005-3013. [CrossRef]

230. Basch, E.M.; Scholz, M.; de Bono, J.S.; Vogelzang, N.; de Souza, P.; Marx, G.; Vaishampayan, U.; George, S.; Schwarz, J.K.; Antonarakis, E.S.; et al. Cabozantinib Versus Mitoxantrone-Prednisone in Symptomatic Metastatic Castration-Resistant Prostate Cancer: A Randomized Phase 3 Trial with a Primary Pain Endpoint. Eur. Urol. 2019, 75, 929-937. [CrossRef]

231. Molife, L.R.; Omlin, A.; Jones, R.J.; Karavasilis, V.; Bloomfield, D.; Lumsden, G.; Fong, P.C.; Olmos, D.; O'Sullivan, J.M.; Pedley, I.; et al. Randomized Phase II Trial of Nintedanib, Afatinib and Sequential Combination in Castration-Resistant Prostate Cancer. Future Oncol. 2014, 10, 219-231. [CrossRef]

232. Dror Michaelson, M.; Regan, M.M.; Oh, W.K.; Kaufman, D.S.; Olivier, K.; Michaelson, S.Z.; Spicer, B.; Gurski, C.; Kantoff, P.W.; Smith, M.R. Phase II Study of Sunitinib in Men with Advanced Prostate Cancer. Ann. Oncol. 2009, 20, 913-920. [CrossRef]

233. Canil, C.M.; Moore, M.J.; Winquist, E.; Baetz, T.; Pollak, M.; Chi, K.N.; Berry, S.; Ernst, D.S.; Douglas, L.; Brundage, M.; et al. Randomized Phase II Study of Two Doses of Gefitinib in Hormone-Refractory Prostate Cancer: A Trial of the National Cancer Institute of Canada-Clinical Trials Group. J. Clin. Oncol. 2005, 23, 455-460. [CrossRef] [PubMed]

234. Curigliano, G.; Braud, F.D.; Sandri, M.T.; Renne, G.; Zorzino, L.; Scardino, E.; Rocco, B.; Spitaleri, G.; Pas, T.D.; Noberasco, C.; et al. Gefitinib Combined with Endocrine Manipulation in Patients with Hormone-Refractory Prostate Cancer: Quality of Life and Surrogate Markers of Activity. Anticancer Drugs 2007, 18, 949-954. [CrossRef]

235. Curigliano, G.; Pelosi, G.; De Pas, T.; Renne, G.; De Cobelli, O.; Manzotti, M.; Spitaleri, G.; de Braud, F. Absence of Epidermal Growth Factor Receptor Gene Mutations in Patients with Hormone Refractory Prostate Cancer Not Responding to Gefitinib. Prostate 2007, 67, 603-604. [CrossRef]

236. Salzberg, M.; Rochlitz, C.; Morant, R.; Thalmann, G.; Pedrazzini, A.; Roggero, E.; Schönenberger, A.; Knuth, A.; Borner, M. An Open-Label, Noncomparative Phase II Trial to Evaluate the Efficacy and Safety of Docetaxel in Combination with Gefitinib in Patients with Hormone-Refractory Metastatic Prostate Cancer. Oncol. Res. Treat. 2007, 30, 355-360. [CrossRef] [PubMed]

237. Small, E.J.; Fontana, J.; Tannir, N.; DiPaola, R.S.; Wilding, G.; Rubin, M.; Iacona, R.B.; Kabbinavar, F.F. A Phase II Trial of Gefitinib in Patients with Non-Metastatic Hormone-Refractory Prostate Cancer. BJU Int. 2007, 100, 765-769. [CrossRef]

238. Curigliano, G.; Spitaleri, G.; Cobelli, O.D.; Scardino, E.; Sbanotto, A.; Braud, F.D. Health-Related Quality of Life in Patients with Hormone Refractory Prostate Cancer Receiving Gefitinib. Urol. Int. 2009, 82, 196-202. [CrossRef]

239. Boccardo, F.; Rubagotti, A.; Conti, G.; Battaglia, M.; Cruciani, G.; Manganelli, A.; Ricci, S.; Lapini, A. Prednisone plus Gefitinib versus Prednisone plus Placebo in the Treatment of Hormone-Refractory Prostate Cancer: A Randomized Phase II Trial. Oncology 2008, 74, 223-228. [CrossRef]

240. Whang, Y.E.; Armstrong, A.J.; Rathmell, W.K.; Godley, P.A.; Kim, W.Y.; Pruthi, R.S.; Wallen, E.M.; Crane, J.M.; Moore, D.T.; Grigson, G.; et al. A Phase II Study of Lapatinib, a Dual EGFR and HER-2 Tyrosine Kinase Inhibitor, in Patients with Castration-Resistant Prostate Cancer. Urol. Oncol. Semin. Orig. Investig. 2013, 31, 82-86. [CrossRef] [PubMed]

241. Gross, M.; Higano, C.; Pantuck, A.; Castellanos, O.; Green, E.; Nguyen, K.; Agus, D.B. A Phase II Trial of Docetaxel and Erlotinib as First-Line Therapy for Elderly Patients with Androgen-Independent Prostate Cancer. BMC Cancer 2007, 7, 142. [CrossRef] [PubMed]

242. Nabhan, C.; Lestingi, T.M.; Galvez, A.; Tolzien, K.; Kelby, S.K.; Tsarwhas, D.; Newman, S.; Bitran, J.D. Erlotinib Has Moderate Single-Agent Activity in Chemotherapy-Naïve Castration-Resistant Prostate Cancer: Final Results of a Phase II Trial. Urology 2009, 74, 665-671. [CrossRef]

243. Gravis, G.; Bladou, F.; Salem, N.; Gonçalves, A.; Esterni, B.; Walz, J.; Bagattini, S.; Marcy, M.; Brunelle, S.; Viens, P. Results from a Monocentric Phase II Trial of Erlotinib in Patients with Metastatic Prostate Cancer. Ann. Oncol. 2008, 19, 1624-1628. [CrossRef]

244. Azad, A.A.; Beardsley, E.K.; Hotte, S.J.; Ellard, S.L.; Klotz, L.; Chin, J.; Kollmannsberger, C.; Mukherjee, S.D.; Chi, K.N. A Randomized Phase II Efficacy and Safety Study of Vandetanib (ZD6474) in Combination with Bicalutamide versus Bicalutamide Alone in Patients with Chemotherapy Naïve Castration-Resistant Prostate Cancer. Invest. New Drugs 2014, 32, 746-752. [CrossRef]

245. Horti, J.; Widmark, A.; Stenzl, A.; Federico, M.H.; Abratt, R.P.; Sanders, N.; Pover, G.M.; Bodrogi, I. A Randomized, Double-Blind, Placebo-Controlled Phase II Study of Vandetanib Plus Docetaxel/Prednisolone in Patients with Hormone-Refractory Prostate Cancer. Cancer Biother. Radiopharm. 2009, 24, 175-180. [CrossRef]

246. Cathomas, R.; Rothermundt, C.; Klingbiel, D.; Bubendorf, L.; Jaggi, R.; Betticher, D.C.; Brauchli, P.; Cotting, D.; Droege, C.; Winterhalder, R.; et al. Efficacy of Cetuximab in Metastatic Castration-Resistant Prostate Cancer Might Depend on EGFR and PTEN Expression: Results from a Phase II Trial (SAKK 08/07). Clin. Cancer Res. 2012, 18, 6049-6057. [CrossRef] 
247. Slovin, S.F.; Kelly, W.K.; Wilton, A.; Kattan, M.; Myskowski, P.; Mendelsohn, J.; Scher, H.I. Anti-Epidermal Growth Factor Receptor Monoclonal Antibody Cetuximab Plus Doxorubicin in the Treatment of Metastatic Castration-Resistant Prostate Cancer. Clin. Genitourin. Cancer 2009, 7, E77-E82. [CrossRef]

248. Fleming, M.T.; Sonpavde, G.; Kolodziej, M.; Awasthi, S.; Hutson, T.E.; Martincic, D.; Rastogi, A.; Rousey, S.R.; Weinstein, R.E.; Galsky, M.D.; et al. Association of Rash with Outcomes in a Randomized Phase II Trial Evaluating Cetuximab in Combination With Mitoxantrone Plus Prednisone After Docetaxel for Metastatic Castration-Resistant Prostate Cancer. Clin. Genitourin. Cancer 2012, 10, 6-14. [CrossRef]

249. Agus, D.B.; Sweeney, C.J.; Morris, M.J.; Mendelson, D.S.; McNeel, D.G.; Ahmann, F.R.; Wang, J.; Derynck, M.K.; Ng, K.; Lyons, B.; et al. Efficacy and Safety of Single-Agent Pertuzumab (RhuMAb 2C4), a Human Epidermal Growth Factor Receptor Dimerization Inhibitor, in Castration-Resistant Prostate Cancer After Progression from Taxane-Based Therapy. J. Clin. Oncol. 2007, 25, 675-681. [CrossRef]

250. Ziada, A.; Barqawi, A.; Glode, L.M.; Varella-Garcia, M.; Crighton, F.; Majeski, S.; Rosenblum, M.; Kane, M.; Chen, L.; Crawford, E.D. The Use of Trastuzumab in the Treatment of Hormone Refractory Prostate Cancer; Phase II Trial. Prostate 2004, 60, 332-337. [CrossRef]

251. Morris, M.J.; Reuter, V.E.; Kelly, W.K.; Slovin, S.F.; Kenneson, K.; Verbel, D.; Osman, I.; Scher, H.I. HER-2 Profiling and Targeting in Prostate Carcinoma: A Phase II Trial of Trastuzumab Alone and with Paclitaxel. Cancer 2002, 94, 980-986. [CrossRef]

252. Lara, P.N.; Chee, K.G.; Longmate, J.; Ruel, C.; Meyers, F.J.; Gray, C.R.; Edwards, R.G.; Gumerlock, P.H.; Twardowski, P.; Doroshow, J.H.; et al. Trastuzumab plus Docetaxel in HER-2/Neu-Positive Prostate Carcinoma: Final Results from the California Cancer Consortium Screening and Phase II Trial. Cancer 2004, 100, 2125-2131. [CrossRef] [PubMed]

253. Aragon-Ching, J.B.; Dahut, W.L. VEGF Inhibitors and Prostate Cancer Therapy. Curr. Mol. Pharmacol. 2009, 2, 161-168. [CrossRef] [PubMed]

254. Kelly, W.K.; Halabi, S.; Carducci, M.; George, D.; Mahoney, J.F.; Stadler, W.M.; Morris, M.; Kantoff, P.; Monk, J.P.; Kaplan, E.; et al. Randomized, Double-Blind, Placebo-Controlled Phase III Trial Comparing Docetaxel and Prednisone With or Without Bevacizumab in Men With Metastatic Castration-Resistant Prostate Cancer: CALGB 90401. J. Clin. Oncol. 2012, 30, 1534-1540. [CrossRef] [PubMed]

255. Tolcher, A.W.; Reyno, L.; Venner, P.M.; Ernst, S.D.; Moore, M.; Geary, R.S.; Chi, K.; Hall, S.; Walsh, W.; Dorr, A.; et al. A Randomized Phase II and Pharmacokinetic Study of the Antisense Oligonucleotides ISIS 3521 and ISIS 5132 in Patients with Hormone-Refractory Prostate Cancer. Clin. Cancer Res. 2002, 8, 2530-2535. [PubMed]

256. Dahut, W.L.; Scripture, C.; Posadas, E.; Jain, L.; Gulley, J.L.; Arlen, P.M.; Wright, J.J.; Yu, Y.; Cao, L.; Steinberg, S.M.; et al. A Phase II Clinical Trial of Sorafenib in Androgen-Independent Prostate Cancer. Clin. Cancer Res. 2008, 14, 209-214. [CrossRef]

257. Aragon-Ching, J.B.; Jain, L.; Gulley, J.L.; Arlen, P.M.; Wright, J.J.; Steinberg, S.M.; Draper, D.; Venitz, J.; Jones, E.; Chen, C.C.; et al. Final Analysis of a Phase II Trial Using Sorafenib for Metastatic Castration-Resistant Prostate Cancer. BJU Int. 2009, 103, 1636-1640. [CrossRef] [PubMed]

258. Pezaro, C.; Rosenthal, M.A.; Gurney, H.; Davis, I.D.; Underhill, C.; Boyer, M.J.; Kotasek, D.; Solomon, B.; Toner, G.C. An Open-Label, Single-Arm Phase Two Trial of Gefitinib in Patients With Advanced or Metastatic Castration-Resistant Prostate Cancer. Am. J. Clin. Oncol. 2009, 32, 338-341. [CrossRef]

259. Dahut, W.L.; Madan, R.A.; Karakunnel, J.J.; Adelberg, D.; Gulley, J.L.; Turkbey, I.B.; Chau, C.H.; Spencer, S.D.; Mulquin, M.; Wright, J.; et al. Phase II Clinical Trial of Cediranib in Patients with Metastatic Castration-Resistant Prostate Cancer: Phase II Cediranib in Advanced Prostate Cancer. BJU Int. 2013, 111, 1269-1280. [CrossRef]

260. Heath, E.; Heilbrun, L.; Mannuel, H.; Liu, G.; Lara, P.; Monk, J.P.; Flaig, T.; Zurita, A.; Mack, P.; Vaishampayan, U.; et al. Phase II, Multicenter, Randomized Trial of Docetaxel plus Prednisone with or Without Cediranib in Men with Chemotherapy-Naive Metastatic Castrate-Resistant Prostate Cancer. Oncologist 2019, 24, 1149. [CrossRef]

261. Barata, P.C.; Cooney, M.; Mendiratta, P.; Gupta, R.; Dreicer, R.; Garcia, J.A. Phase I/II Study Evaluating the Safety and Clinical Efficacy of Temsirolimus and Bevacizumab in Patients with Chemotherapy Refractory Metastatic Castration-Resistant Prostate Cancer. Invest. New Drugs 2019, 37, 331-337. [CrossRef]

262. Picus, J.; Halabi, S.; Kelly, W.K.; Vogelzang, N.J.; Whang, Y.E.; Kaplan, E.B.; Stadler, W.M.; Small, E.J.; Cancer and Leukemia Group B. A Phase 2 Study of Estramustine, Docetaxel, and Bevacizumab in Men with Castrate-Resistant Prostate Cancer: Results from Cancer and Leukemia Group B Study 90006. Cancer 2011, 117, 526-533. [CrossRef] [PubMed]

263. Choi, Y.J.; Kim, H.S.; Park, S.H.; Kim, B.-S.; Kim, K.H.; Lee, H.J.; Song, H.S.; Shin, D.-Y.; Lee, H.Y.; Kim, H.-G.; et al. Phase II Study of Dovitinib in Patients with Castration-Resistant Prostate Cancer (KCSG-GU11-05). Cancer Res. Treat. 2018, 50, 1252-1259. [CrossRef] [PubMed]

264. Sridhar, S.S.; Joshua, A.M.; Gregg, R.; Booth, C.M.; Murray, N.; Golubovic, J.; Wang, L.; Harris, P.; Chi, K.N. A Phase II Study of GW786034 (Pazopanib) With or Without Bicalutamide in Patients With Castration-Resistant Prostate Cancer. Clin. Genitourin. Cancer 2015, 13, 124-129. [CrossRef]

265. Tannock, I.F.; Fizazi, K.; Ivanov, S.; Karlsson, C.T.; Fléchon, A.; Skoneczna, I.; Orlandi, F.; Gravis, G.; Matveev, V.; Bavbek, S.; et al. Aflibercept versus Placebo in Combination with Docetaxel and Prednisone for Treatment of Men with Metastatic Castration-Resistant Prostate Cancer (VENICE): A Phase 3, Double-Blind Randomised Trial. Lancet Oncol. 2013, 14, 760-768. [CrossRef] 
266. Stadler, W.M.; Cao, D.; Vogelzang, N.J.; Ryan, C.W.; Hoving, K.; Wright, R.; Karrison, T.; Vokes, E.E. A Randomized Phase II Trial of the Antiangiogenic Agent SU5416 in Hormone-Refractory Prostate Cancer. Clin. Cancer Res. 2004, 10, 3365-3370. [CrossRef]

267. Figg, W.D.; Dahut, W.; Duray, P.; Hamilton, M.; Tompkins, A.; Steinberg, S.M.; Jones, E.; Premkumar, A.; Linehan, W.M.; Floeter, M.K.; et al. A Randomized Phase II Trial of Thalidomide, an Angiogenesis Inhibitor, in Patients with Androgen-Independent Prostate Cancer. Clin. Cancer Res. 2001, 7, 1888-1893.

268. Drake, M.J.; Robson, W.; Mehta, P.; Schofield, I.; Neal, D.E.; Leung, H.Y. An Open-Label Phase II Study of Low-Dose Thalidomide in Androgen-Independent Prostate Cancer. Br. J. Cancer 2003, 88, 822-827. [CrossRef] [PubMed]

269. Antonarakis, E.S.; Heath, E.I.; Smith, D.C.; Rathkopf, D.; Blackford, A.L.; Danila, D.C.; King, S.; Frost, A.; Ajiboye, A.S.; Zhao, M.; et al. Repurposing Itraconazole as a Treatment for Advanced Prostate Cancer: A Noncomparative Randomized Phase II Trial in Men with Metastatic Castration-Resistant Prostate Cancer. Oncologist 2013, 18, 163-173. [CrossRef]

270. Albanell, J.; Rojo, F.; Averbuch, S.; Feyereislova, A.; Mascaro, J.M.; Herbst, R.; LoRusso, P.; Rischin, D.; Sauleda, S.; Gee, J.; et al. Pharmacodynamic Studies of the Epidermal Growth Factor Receptor Inhibitor ZD1839 in Skin from Cancer Patients: Histopathologic and Molecular Consequences of Receptor Inhibition. J. Clin. Oncol. 2002, 20, 110-124. [CrossRef]

271. Pin, E.; Stratton, S.; Belluco, C.; Liotta, L.; Nagle, R.; Hodge, K.A.; Deng, J.; Dong, T.; Baldelli, E.; Petricoin, E.; et al. A Pilot Study Exploring the Molecular Architecture of the Tumor Microenvironment in Human Prostate Cancer Using Laser Capture Microdissection and Reverse Phase Protein Microarray. Mol. Oncol. 2016, 10, 1585-1594. [CrossRef] 